\title{
Article \\ The Complexity of Logistics Services at Transshipment Terminals
}

\author{
Ludmiła Filina-Dawidowicz ${ }^{1, *(1)}$ and Mariusz Kostrzewski ${ }^{2, * \text { (D) }}$ \\ 1 Department of Logistics and Transport Economics, Faculty of Maritime Technology and Transport, \\ West Pomeranian University of Technology in Szczecin, al. Piastów 41, 71-065 Szczecin, Poland \\ 2 Division of Construction Fundamentals of Transport Equipment, Faculty of Transport, \\ Warsaw University of Technology, ul. Koszykowa 75, 00-662 Warsaw, Poland \\ * $\quad$ Correspondence: ludmila.filina@zut.edu.pl (L.F.-D.); mariusz.kostrzewski@pw.edu.pl (M.K.)
}

Citation: Filina-Dawidowicz, L.; Kostrzewski, M. The Complexity of Logistics Services at Transshipment Terminals. Energies 2022, 15, 1435 . https://doi.org/10.3390/en15041435

Academic Editor:

Arkadiusz Swiadek

Received: 24 January 2022

Accepted: 14 February 2022

Published: 16 February 2022

Publisher's Note: MDPI stays neutral with regard to jurisdictional claims in published maps and institutional affiliations.

Copyright: (c) 2022 by the authors. Licensee MDPI, Basel, Switzerland. This article is an open access article distributed under the terms and conditions of the Creative Commons Attribution (CC BY) license (https:/ / creativecommons.org/licenses/by/ $4.0 /)$.

\begin{abstract}
Transshipment is the process of off-loading an intermodal loading unit (for example, different types of containers, semitrailers, swap-bodies, and so on) from one means of transport (for example, a vessel, a freight railcar, etc.) and loading it onto another. Such a process, as well as other logistics services related to loading units, may take place at a transshipment terminal, which is the intermediate node added to an intermodal transport network when combining two or more liner services that facilitate freight transport. Growing customer requirements affect transshipment terminal operations and contribute to the development of comprehensive logistics services. Terminal clients expect the delivery of complex services that often pose serious challenges to terminals providing these services. The specific decision-making tools are essential for facilitating the shaping of terminals complex service offerings. In this study, we investigated the issues connected to the complexity of logistics services offered by transshipment terminals. The aim was to develop a decision-making approach to assess the complexity of logistics services offered by these terminals. A procedure for the formulation of complex and comprehensive service sets at transshipment terminals, which includes sustainable energy and energy efficiency issues, was proposed. The approach for assessing the complexity of services at terminals handling intermodal loading units was developed, and an appropriate mathematical model was applied. Consequently, indexes of the efficiency and comprehensiveness levels of ordered services in a terminal were proposed. The ranking of decision-making criteria influencing the shaping of complex service offerings was created based on the results of a questionnaire survey distributed among the managerial representatives of terminals located in Poland. The data obtained with the use of a questionnaire survey allowed us to verify the proposed approach. The research results may be useful for the management of transshipment terminals while making decisions on the creation of comprehensive services offered to their clientele.
\end{abstract}

Keywords: transshipment terminal; intermodal loading unit; comprehensive logistics service; service complexity; offering complexity

\section{Introduction}

Transshipment is the process of off-loading an intermodal loading unit (ILU) from one means of transport (for example, a vessel, a freight railcar, etc.) and loading it onto another. A transshipment terminal is the intermediate node added to an intermodal transport network when combining/linking two or more liner services [1]. Transshipment terminals play a significant role in efficient freight delivery as an important link of intermodal transport chains, as has been mentioned by Zhang et al. [2] and other researchers. As a part of transport and logistics systems, the terminals provide material handling and allow for transshipment between various transport modes. The infrastructure and equipment of transshipment terminals provide handling of ILUs (including different types of containers, semitrailers, swap-bodies, and so on) $[3,4]$. This term has been approved by the directive on intermodal loading units of the European Parliament and Council [5]. 
Changes in the role of transshipment terminals, designated to serve ILUs, have been observed during the last decade. Such terminals do not serve solely as handling points anymore. On the contrary, they are treated as spaces where various services for the terminals' clientele are performed [6,7]. These services include ILU weighing, cleaning, formation, quality control, and so forth. Customers expect to receive comprehensive cargo service at one designated location, where a set of individual services performed by one company (also referred to as "entity" herein) is offered. This is also a significant aspect in the case of energy saving and environmental protection; the fewer the number of responsible service providers per order, the less energy is consumed, which in turn can lead to a reduction in negative environmental impacts. Shifting from fossil fuels to electricity and energy efficiency is a matter of terminal operations, as was mentioned by Wilmsmeier et al. [8,9]. Traditionally, the following means of transport have been powered by diesel: ship-to-shore cranes, mobile cranes, rail-mounted gantry cranes, rubber-tired gantry cranes, reach stackers, straddle carriers, tractor-trailer units, and lorries. Currently, all of them can be powered by electricity $[8,10]$. Various researchers have investigated sustainable energy issues and have discovered methods for reducing energy consumption. For example, Ye et al. [11] suggested that liquefied natural gas import terminals can reduce energy consumption by cold energy recovery of the gas or a boil-off gas handling process. Energy reduction led Alzahrani et al. [12] to review methods for the decarbonization of seaports (seaports are infrastructure facilities that conduct transshipment processes as well), which also can lead to a reduction in energy waste. Moreover, energy consumption can be reduced by proper service operations that are adequately designed and developed.

Management representatives and employees of transshipment terminals make an effort to anticipate and shape their service offerings in order to meet customers' expectations. On the one hand, such an approach may trigger problems and challenges related to the selection of services shaping a particular offer of a transshipment terminal. On the other hand, it may also lead to meeting customer satisfaction and, consequently, influencing the profitability of a terminal itself. Moreover, the management representatives of such terminals have to assess the convergence of the suggested offer with customers' expectations in terms of its complexity. The managers require specific tools in order to facilitate an offer while making rational decisions on shaping the terminal's services. According to a conducted review of the available literature, the issues related to the problems of comprehensive ILU services at transshipment terminals have not been widely discussed so far. Merely selected challenges of terminal services have been analyzed in detail. A research gap was identified in the field of shaping comprehensive service offers for ILUs in transshipment terminals. This finding is supported by the panoramic literature analysis presented in Section 2 of this article. The research gap was outlined, preceded by a comprehensive literature revision, and the components of this gap are presented. The available publications do not contain detailed descriptions of comprehensive service sets in transshipment terminals in terms of service assessment; nevertheless, individual literature items regarding the inclusion of selected services in a comprehensive evaluation have been considered, for example [6,13-15] (the details are given in Section 2 of this paper). A lack of a comprehensive and straightforward decision-making approach of multiple factors (decision-making criteria) that support the shaping of transshipment terminal service offers and the assessment of their complexity considering the wide range of performed logistics services was observed.

Therefore, the aim of the paper was to develop a fundamental decision-making approach to assess the complexity of ILU logistics services at transshipment terminals. The goal of this instrument is to assist in the multi-factor decision-making process during the shaping of service offers in a particular transshipment terminal.

The following research questions were formulated:

(1) How can the complexity of services be assessed?

(2) What criteria are the most important from the perspective of a particular transshipment terminal's representatives in the shaping, development, and extension of a transshipment terminal's comprehensive service offers? 
The article describes the issue of ILU comprehensive services in more detail. A procedure for the formulation of a set of comprehensive services at transshipment terminals is proposed, and a method of assessing the complexity of ILU services at transshipment terminals is elaborated. For this purpose, a certain set of decision-making criteria was formulated. A binary system was used to determine the fulfillment or lack of particular criteria. In addition, a method of calculating the level of comprehensiveness (complexity) of a service offering is proposed, and examples of acceptance ranges of the level of complexity of ILU services at transshipment terminals are suggested. An index of ordered service efficiency in a terminal is proposed as well.

The article focuses on transshipment terminals as entities that are primarily related to the profitability of their operations. A case study of transshipment terminals located at container and ferry terminals, as well as road-rail terminals in Poland, was analyzed. A questionnaire was developed, and the survey was carried out in June-July 2020 among the terminal managers. The viewpoints of the terminal representatives who were willing to express their insights, and who are directly responsible for the shaping of the comprehensive services/offers, were taken into consideration. The questionnaire survey was used to collect necessary data to verify the proposed approach. Based on the survey results, the ranking of the decision-making criteria influencing the shaping of the comprehensive service offerings was achieved, and the proposed approach was validated.

Section 2 of the paper presents a detailed literature review that proves that comprehensive and clear decision-making tools employed in shaping sets of complex/comprehensive services have not been developed yet. The methodological part of the paper, the accurate results, and a meticulous discussion are presented in the following consecutive sections. The paper is summarized with a discussion, conclusions, and future potential research interests.

\section{Literature Review}

The issues of shaping a transshipment terminal's comprehensive service offerings led the authors to develop a panoramic review as a comprehensive and thematically extensive presentation of the issue.

The available literature widely describes the issues of transport and logistics system functioning, including problems of the intermodal transport processes within these system structures [16-23]. Different approaches related to providing transport services were distinguished, including those based on the conventional conceptualization, the idea of comprehensive transport service, and the concept of comprehensive logistics services [13,24-26]. The last concept includes a set of coordinated activities related to the transport of cargo from the dispatch location to the destination of the goods. The process is organized by a transport process operator (or a logistics operator) who undertakes the implementation of all actions and activities related to the handling of the goods and their shipment, including the transport process as well as transport operations [6]. This concept assumes that the scope of the transport services within the transport chain includes the logistics services that may be undertaken at different nodes of this chain, such as transshipment terminals [24].

The analyses of world-renowned scientific databases proved that comprehensive services in connection to intermodal transport are a rare subject of interest. For example, the search of the Web of Science database with the keywords "comprehensive service*" AND "intermodal transport" at the time returned only 10 records-one publication from 2020, two from 2019, four from 2017, one from 2016, and two from 2015 (date of analysis-29 April 2020). Meanwhile, searching the Scopus database with the same set of keywords, eight records were found-two publications from 2020, two from 2019, two from 2017, one from 2016, and two from 2006 (date of analysis-29 April 2020). Five publications are indexed in both databases; therefore, it can be assumed that only thirteen papers and proceeding materials related to the keyword set have been published so far. Nevertheless, after detailed analyses, it was assumed that most of the mentioned papers do not concern "comprehensive services" in the way the authors of this contribution approached the topic. 
Among the rare cases that correspond to "comprehensive services", the paper of Beškovnik and Stojaković [14] can be mentioned, in which the authors described stakeholders providing a comprehensive overview of the possibility of introducing new kinds of small consignment services. From the perspective of the current research, another paper of interest is that of Antonowicz [27], whose research revealed that the services offered by an intermodal transport operator can be considered a complex systemic intermodal service.

As it has been mentioned in a broad range of scientific publications related to transport and logistics, services can be carried out for ILUs (e.g., containers, semitrailers, swapbodies, intermodal wagons, etc.) at transshipment terminals that are allocated in sea- or inland ports on the premises of intermodal terminals, logistics centers, and so on. In the premises of these terminals, various operations and services are carried out to allow for the continuation of ILU transport processes [28]. An extensive review of transport operations in container terminals was conducted by Héctor et al. [29,30]. Steenken et al. [31] classified the main logistics processes and operations performed at these terminals. Transshipment operations of ILUs may be carried out in rail-rail, rail-road, sea-rail, sea-road, and other relations with the use of custom facilities and equipment [32,33]. Attention was drawn to the fact that currently, operations at transshipment terminals are not possible without effective and efficient information flow, the use of information technology, and appropriate optimization methods [31,34,35]. All these aspects, in the opinion of the authors of this paper, may significantly contribute to the development of the subject of comprehensive service offerings.

It should be emphasized that both internal and external factors influence the functioning of such terminals [36-38]. Intense competition between intermodal cargo transport networks was observed [39-42]. Moreover, the majority of transshipment markets, similarly to main-haulage markets, were characterized as highly concentrated [5]. These factors affect the necessity of developing terminal individual business strategies, including the service shaping of competitive and comprehensive offerings. However, the available studies do not contain detailed descriptions of sets of comprehensive services in transshipment terminals.

The main purpose of a comprehensive service is to provide comprehensive logistics services for cargo, which is linked to the need to shape an appropriate service offering and rationalize all the processes and procedures that occur during this offer implementation, The operational costs, delivery time, and safety of the cargo are also affected. Such service offers should be open-ended, allowing for the inclusion of new individual services and the addition of new subcontractors, as well as enabling the potential implementation of innovations and new knowledge. For example, the implementation of smartphone applications ensures the convenient ordering and monitoring of the execution of a particular service [13]. It should be noted that an attempt was made to describe these service implementations for refrigerated container transportation [6]; however, the study did not refer to transshipment terminals operating other types of ILUs.

A comprehensive logistics service should meet the customer's requirements and expectations in terms of punctuality, compatibility, and flexibility [43-46]. These requirements must be considered by terminal operators during the shaping of an offer of proposed services [47]. Such an offer must be examined in a continuous manner. As an example, a survey tool has often been used to examine user satisfaction regarding the quality of the terminal facility and service level $[48,49]$. An evaluation of customer satisfaction in container ports was carried out by Jafari et al. [50]. Gajewska and Grigoroudis [51] focused on the importance of logistics service attributes influencing customer satisfaction. Kilibarda et al. [52] presented a literature review on logistics service quality. These authors mentioned that there were not enough approaches or models that deal comprehensively with the issue of logistics services and their systematization. It should be highlighted that Kilibarda et al. [52] developed a comprehensive review of logistics services; nevertheless, they did not define any model (as it was not the aim of their review). They highlighted time delays as a cause of low-quality service and dissatisfaction among customers. Kilibarda et al. [52] 
also reported selected indicators for analyses of the quality of logistics services. These indicators are mentioned in a number of research papers, as follows:

1. Gil Saura et al. [53] — these researchers analyzed the influence of the quality and timeliness of logistics services on satisfaction, which, according to the authors, can result in customer loyalty;

2. Feng et al. [54] — timeliness was mentioned by these authors together with other qualitative variables and factors, such as personal contact quality, order quality, order discrepancy handling, order condition, and convenience;

3. Tian et al. [55], Millen et al. [56] — these researchers also considered timeliness, defining it as deliveries provided on time;

4. Gotzamani et al. [57] - the following indicators in the order of appearance were mentioned: on-time delivery, error-free transactions, consistency of order cycle, no goods damaged in handling or delivery, no stock-outs defined in the procedures or logistics services instructions, accurate inventory, information-reliable suppliers; a general remark of the authors was that third-party logistics (3PL) companies provide higher quality logistics services;

5. Kilibarda et al. [58] — the authors highlighted that the delivery of goods significantly influences the quality of logistics services;

6. Sohn et al. [59] - the ability to provide IT-based solutions was analyzed; additionally, the authors observed some applications of "must-be" quality that do not contribute to customer satisfaction;

7. Murfield et al. [60] - these researchers considered delivery on time; in their opinion, timeliness is the driver of consumer satisfaction and loyalty in omni-channel environments;

8. Mentzer et al. [61] —order processing, order assembly, and delivery were mentioned by the authors as activities of no consequence to a customer in physical distribution service, contrary to the quality and timeliness of their performance;

9. Rafele [62] - the author considered the level of service in relation to the overall service as an indicator, that is, the effect of activities on customers, which was assessed as the number of deliveries per number of orders;

10. Kisperska-Moron [63] — the author selected indicators and factors such as lead time, promptness of deliveries, precision of delivered assortment, flexibility of deliveries, availability of additional services, quality of delivered products;

11. Mentzer et al. [64] — these authors' choices of indicators and factors were as follows: quality of contact with personnel, order release quantities, information quality, ordering procedures, order accuracy, order condition, order quality, order discrepancy handling, and timeliness;

12. Juga et al. [65] — the groups of indicators that were considered were focused on operational service quality, personal service quality, and technical service quality;

13. Rafiq and Jaafar [66] — functional measures were regarded as excellent quality indicators in the sector, whereas technical measures, such as order quality, order release quantities, and order accuracy, were considered less appropriate;

14. Sohal et al. [67] —failures in logistics processes were investigated; in turn, Gotzamani et al. [57] reported an observed lack of interest in the case of service quality implementation;

15. Refs. [68-71] —in the case of these papers, flexibility, elasticity, and reliability were of interest to the author; according to Hartmann and De Grahl [70], flexibility is a valuable and distinctive ability of a logistics service provider, as well as a key driver of successful relationships with customers; it is also worth mentioning that Liu and Xie [72] developed an expected revenue model with consideration for the quality decision making of logistics services supply chains with predefined game models (nevertheless, it should be highlighted that an indicator itself may not take into consideration the significant aspects of the services). 
Following the review conducted by Kilibarda et al. [52], an empirical study of service attributes at container terminals was done by Lu et al. [71]. The motivation of terminal operators behind a competitive service offering was analyzed by Protic et al. in order to identify value-added services [7].

Among the wide range of issues, the complexity of services was often mentioned, as it can be observed in the above-referenced research; however, a method for its unambiguous assessment has not been described in a clear manner in relation to ILU services at transshipment terminals. Such a method should include the consideration of formal modeling. Formal modeling can be found in selected research contributions, such as that of Liu and Xie [72]; however, firstly, it is a very rare approach, and secondly, it only considers selected factors and ratios. Therefore, a complex solution is still of utmost necessity.

The necessity of high-quality service performance for ILUs was highlighted in the literature as well. Pham and Yeo [73] investigated the service quality of transshipment container terminals in Vietnam from the perspective of shipping companies. The consistent fuzzy preference relation method has been introduced to solve multicriteria service quality problems with the use of both empirical data and expert knowledge. The quality of services for refrigerated containers in Poland from the perspective of container terminals was investigated by Filina-Dawidowicz and Gajewska [43]. Ma et al. [74] analyzed the performance of the two resource-sharing strategies in a container terminal in Hong Kong with respect to operating costs, service quality level, and operations efficiency. In the study by Wei et al. [75], the efficiency of load transshipment at a port railway container intermodal terminal mainly depended on factors such as the arrival time, loading rate, and cargo volume. The authors also brought to attention the implementation of quality management systems that influence the quality of performed operations [76]. According to Pujats et al. [40], operators of container terminals are always seeking better policy and operational plan developments. The authors of the mentioned paper reviewed and investigated seaport and container terminal competition and cooperation involving various stakeholders.

Different approaches for the assessment of terminal operations have been developed. Castilla-Rodríguez et al. [77] stated that terminal managers deal with an extensive variety of interrelated logistics problems, and the effectiveness and productivity of the terminal greatly depend on their solution. Pokrovskaya and Fedorenko [78] developed methods for the integrated assessment of the parameters of terminals and other logistics facilities based on the total rating and applied assessment tools used for carrying out an analysis of the activities carried out these locations on several key parameters. The potential implications of the identified core characteristics of service in three areas of transport practices, as examined by Jittrapirom et al. [79], are as follows: travel demand modeling, a supply-side analysis, and business model design. Chao and Chen [80] formulated a general time-space model to reposition reefer containers among selected Asian seaports. Costea et al. [81] defined a model for the assessment of the quality of time in terms of waiting time, taking into consideration a terminal's activity based on the ships' traffic coefficient in the seaport. It was also highlighted that transshipment terminals should be designed to allow for the implementation of potential innovations [44]. The innovations are then evaluated by the increase in performance for the total intermodal transport solution. For example, Jiang et al. [82] observed that in order to meet the growing customer demands, port operators are in need of sustainable solutions and have to adopt automated container terminals (ACTs) while considering aspects of ecology.

The problems of shaping services were also described in the literature. According to Solak Fişkin et al. [15], the increasing interest in intermodal transport expressed by stakeholders, such as shippers and carriers, has led logistics service providers and transport operators to expand their offerings with the latest intermodal transport services. The authors also identified the common stages of newly developed services in the processes of intermodal transport. Alam and Perry [83] introduced a customer-oriented service development process that was new at the time, but is still worth mentioning. They suggested the 
following methodology for the process: firstly, obtain customer input through meetings between customers and a stakeholder development team, then observe customers and occasionally carry out detailed questionnaires at selected stages in the development process in order to generate innovative insight. Likewise, Shekar [84] elaborated an innovative model of service development that incorporates the participation of users and service staff (which might be also understood as a stakeholder development team). This kind of cooperation is related to the awareness that the development of products and services is a result of business activity that is based on the knowledge of employees-understood here as service staff [85]. The high importance of analyzing applied and newly designed workflows to find the optimal method of operations and achieving the best possible performance while taking into consideration the significant role of engineers, who have the appropriate knowledge and abilities, was also highlighted [86]. Furthermore, Calderón and Miller [87] conducted a comprehensive literature review focused on the supply aspect of mobility services, providing relevant insights at three different levels of services development: conceptual, operational, and modeling. Kamargianni et al. [88] reviewed up-to-date mobility services and suggested the application of an index to evaluate the level of mobility integration for each service. The index assumes that a higher level of integration is more appealing to customers. Macharis et al. [89] proposed the setup of a web-based tool designed to support customers, enabling them to check if intermodal transport is appropriate for them. The analyzed literature references revealed only selected problems of service shaping in the sphere of transport, and do not present the complex view of comprehensive services of ILUs at transshipment terminals.

It should be highlighted that terminal management representatives have their own viewpoints on shaping services. Terminal customers usually determine the demand for services; however, the final decision for launching the services is made by the terminal managerial offices. These decisions may be influenced by the ability to finance an investment on their own or with a loan, legal restrictions, available employees, technical equipment, and so on. Therefore, the insight of terminal representatives and their customers should be investigated to determine what their viewpoints are on the aspects considered while shaping the service offerings.

Transport and logistics markets put high demands on swift decision-making and economic feasibility [78]. Therefore, decision-making models should be improved in order to support the safe and efficient performance of transport tasks. In their research, Legato and Mazza [38] discussed certain open modeling issues and encouraging results. As a result, they provided selected guidelines for future research associated with the adaption of container terminal logistics under the large range of techniques and algorithms that are available nowadays for supporting long-term decision making. Tong and $\mathrm{Xu}$ [90] investigated the problems of making the optimal decisions for deliveries to transshipment terminals with multi-location inventory (this topic was also considered by Ližbetin [91]). According to decision models, the optimal mode of transshipment distribution was obtained based on a set of parameters that ensure the same spatial displacement, fewer expenditures, reduction in the transportation time of goods in transit, and warranty of cargo safety. Zhang et al. [2] demonstrated a solution in a cost-benefit analysis context with user valuations of intermodal freight transport reliabilities. The authors proved as well that projects for the renovation and expansion of a transshipment terminal were found to be more effective compared to a project that improves the rail haulage speed. It is worth noting that nowadays, many services are performed under outsourcing agreements, and the appropriate decisions in this context should be taken into consideration [92]. Multicriteria analyses were also applied to solve transport and logistics issues [89,93,94]. The models presented in the previously mentioned publications are not applied to assess the service complexity of a transshipment terminal; however, they can become significant supports in terms of achieving such an objective. Nevertheless, this does not mean that multicriteria analyses do not apply to the assessment of service complexity. 
Many reference items in the available literature describe the issues of services offered in public transport and the approaches for their shaping, which might be implemented into an ILU comprehensive service set. In their research, Guidon et al. [95] discussed approaches to service merging in the passenger transportation market known as mobility as a service (MaaS) [96]. They stated that in a competitive market, the potential success of MaaS fusion follows consumer valuation of the service fusion as compared to the valuation of standalone services. Such a statement emphasized that customers are willing to purchase fusion services depending on the service structure. Yang et al. [97] introduced a new approach based on degree centrality (the primary measure for evaluating the importance of nodes in a network) and a gravity model to assess the comprehensive public transport service accessibility. The gravity model is understood as a measure for the relationship between two nodes in a network, which is positively correlated with connections of two nodes, and inversely correlated with impedances such as time, distance, and costs. A comprehensive public transport service accessibility index was formulated for modeling a public transport network configuration by Yang et al. [97] to quantify accessibility at the community level. In turn, Moskolai et al. [98] proposed an ontology-based approach for complexity management in the design of a sustainable urban mobility system. The suggested method combines approaches of engineering systems and knowledge engineering to manage the complexity of assessing the sustainability of an urban mobility system.

Protic et al. [7] revealed a terminal operator's motives behind a competitive service offering to identify promising new value-added services and investigated the impact of the implementation of a new service on a terminal's performance. The analysis showed various impacts of new services on a terminal's performance and highlighted the importance of understanding the cascade effects of management decisions in intermodal inland terminals.

The authors of the current paper briefly reviewed significant aspects, research approaches, and contributions related to the matter of services at transshipment terminals, which are important from the viewpoint of the development and assessment of comprehensive service offerings. As was mentioned above, the comprehensiveness of services is an identified approach; nevertheless, there is a lack of research in relation to ILU services at transshipment terminals. The analyzed publications of the scientific community of transport revealed only selected problems and challenges of service shaping in the sphere of transshipment terminals, and the shaping of neither complex nor comprehensive service offerings of ILUs was noticed or confirmed. The authors distinguished various approaches and methods for service quality assessment, as follows:

1. SERVQUAL - this model analyzes the difference between the user's perception and expectations [99-102]; the model was mentioned in Kilibarda et al. [52] as not very universal across the business, that is, in the logistics sector;

2. SERVPERF - this model was presented by, for example, Cronin and Taylor [103]; however, this logistics service quality model, which focuses on processes and uses a Likert scale, is believed to be seldom operated in markets other than the United States (according to [52]);

3. Kano model-this model considers attractive attributes, one-dimensional attributes, and must-be attributes for a service quality assessment [54],

4. Statistical approaches, standards (e.g., ISO standards), and other approaches, such as regression analysis, that identify the relationships between a perfect company's internal and external operational quality practices [104];

5. Exploratory factor analysis (EFA) and confirmatory factor analysis (CFA) [105];

6. ANOVA and linear regression $[56,68]$.

In rare cases, these models are combined into a hybrid one, such as the model applied by Baki et al. [106].

This paper's research gap was identified to cover the lack of the following aspects:

1. A comprehensive and clear decision-making approach that supports management representatives of transshipment terminals in shaping comprehensive service offers, 
2. Criteria set for decision-making regarding a comprehensive service at transshipment terminals that may be used by management representatives of transshipment terminals;

3. Decision-making models that allow for assessing the complexity of services offered by transshipment terminals to their clientele considering the wide range of performed logistics services.

All of the above-mentioned aspects justify the need to research the assessment of the complexity of services offered by transshipment terminals.

\section{Materials and Methods}

To execute the presented research, the authors developed and applied a methodology covering several steps, which are presented in Figure 1.

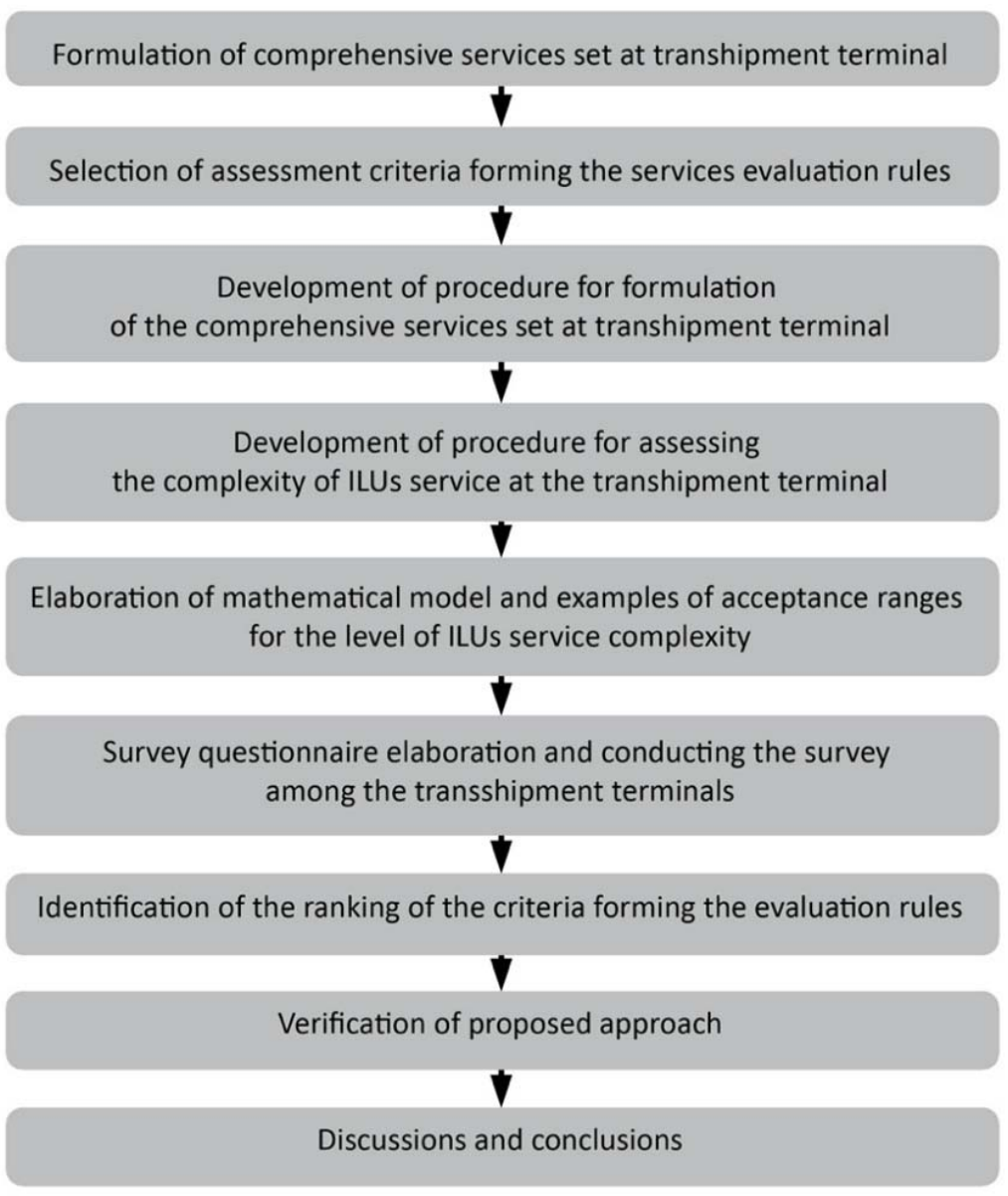

Figure 1. Steps of the research methodology.

As a result of the literature review and actual research analysis, the issues with sets of comprehensive services at transshipment terminals are described in more detail. Attention was paid to various services that may shape the service offers of transshipment terminals. Firstly, it was assumed that the aspect of terminal profitability would be analyzed in detail, without direct consideration of the social and environmental aspects influencing terminal operations. Based on such an assumption, certain assessment criteria enabling the service evaluation rules were selected. These criteria are intended for decision-makers who may consider them to assess the possibility of adding a potential new service to the whole service offering.

The method of selecting services and appending them to the comprehensive service offering of a transshipment terminal was identified and the procedure for the formula- 
tion of a set of comprehensive services at a transshipment terminal was proposed. The objective function optimization in this research is the maximization of the level of the comprehensiveness of services at a particular transshipment terminal.

A method of decision-making was developed as well. A procedure for assessing the complexity of a logistics service at a particular transshipment terminal was elaborated, and a mathematical model that enables the calculation of the level of service complexity was proposed. A binary system was used to examine the criteria fulfillment. An index of ordered service efficiency in a transshipment terminal was suggested as well. Examples of acceptance ranges for the level of ILU service complexity at a particular transshipment terminal were introduced to show the possibilities of applying the computation results.

The procedure and approach presented in this paper are enriched with a case study of transshipment terminals located in Poland. The case study was analyzed, and a marketing research tool was used in order to collect the information necessary to verify the developed approach and mathematical model. To enable such an effect, the survey questionnaire was developed and sent in an electronic format to representatives of 32 transshipment terminals. The target audience covered transshipment terminals of different kinds, including maritime container terminals, ferry terminals, and railroad intermodal terminals. Available terminals were qualified to take part in the research; the selection of terminals allowed us to investigate the services of different ILU types in terminals located both in seaports and the hinterlands. Additionally, phone calls were made to inform the terminal representatives about the conducted survey and to strengthen their interest in the conducted research. The survey was carried out from 12 June to 7 July 2020.

The authors obtained the insights of 10 terminal representatives who expressed their willingness to complete the questionnaire (the return rate was equal to 0.3125). The questionnaires were filled out by representatives of transshipment terminals responsible for decision-making processes related to the shaping of comprehensive service offerings. These terminals are located in the following voivodeships of Poland: Greater Poland (Wielkopolskie), Masovia (Mazowieckie), Lodz (Łódzkie), Pomerania (Pomorskie), Silesia (Ślaskie), and West Pomerania (Zachodniopomorskie). Four of the mentioned terminals are situated within seaport premises (container and ferry terminals), and the other six terminals are considered rail-road terminals. The analyzed terminals provide mainly international operations; only one terminal's representative declared that the terminal's activity is related solely to domestic transport connections. It should be highlighted that it does not matter whether the considered terminals provide domestic or international operations from a practical point of view, as they engage in the same basic operations. The analysis of the achieved results allowed us to investigate transshipment terminal viewpoints on the importance of the criteria used for decision-making.

Based on the collected information, the ranking of the analyzed criteria was developed. This allowed us to determine the most important criteria used to make a decision regarding a particular service from a transshipment terminal perspective. The achieved results constituted the input data for the developed model and were also used to validate the developed approach.

Finally, the research results were discussed, and conclusions were drawn. Moreover, further research directions are suggested.

\section{Results}

\subsection{Formulation of Comprehensive Services Set at Transshipment Terminal}

As it was stated in Section 3, a comprehensive ILU service covers all the operations ensured by a single entity responsible for the implementation of operations. In the case of such an approach, a particular customer does not order various services from several suppliers but instead receives all necessary services from a single entity. Such an approach ensures proper, functional, and effective cargo handling. Such an entity can be a terminal operator, freight forwarder, logistics operator, or another participant in a particular transport chain. The execution of ILU services by a single operator is facilitated by a set of comprehensive 
services. The operator is responsible for ensuring the integrity of all processes implemented in a terminal for cargo service. The method for providing a comprehensive ILU service in a transshipment terminal is presented in Figure 2.

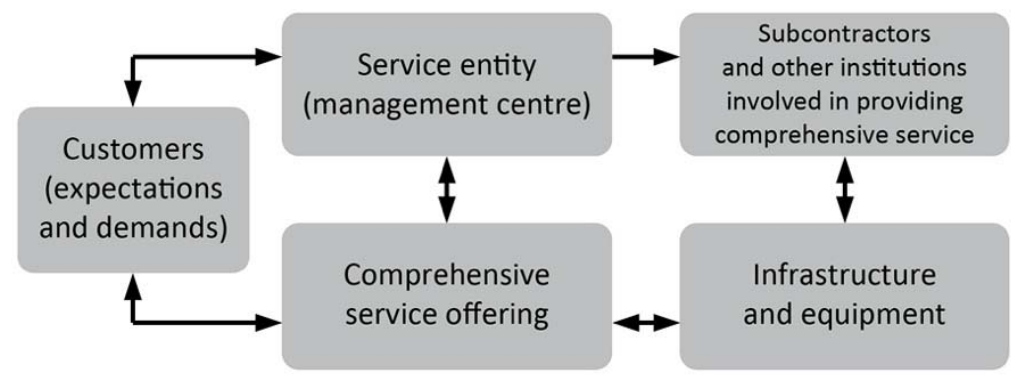

Figure 2. The method of providing comprehensive services in a transshipment terminal. Source: own elaboration, based on [26].

There are numerous services that are performed at transshipment terminals. These services may cover standard services, such as overloading operations, storage, and ILU movement on terminal territory, as well as additional services (tailored for the specific terminal's needs), including ILU forming, weighing, cleaning, cargo quality control, and so forth (Table 1). Particular transshipment terminals develop their own offerings. It should be mentioned that a much broader range of services is performed for different container types in comparison to other kinds of ILUs. For example, refrigerated containers should be additionally plugged into an electricity supply system located at a terminal, and the temperature inside these load units should be monitored in a regular manner. Moreover, the usage of transshipment terminals extends the range of services with so-called logistics services, including the completion and unloading of ILUs, providing customers with information on cargo service status, cargo distribution, insurance and advertisement, organization of the intermodal transport chain, external expert opinions and consultancy, and more.

Table 1. Exemplification of selected services performed as part of ILU operations at transshipment terminals.

\begin{tabular}{ccc}
\hline ILUs & Standard Services & Additional Services \\
\hline Container & Overloading & Cleaning \\
Semitrailer & Storage & Weighing \\
Swap-body, etc. & Movement on a terminal & Repair \\
& territory, etc. & Scanning \\
& & Cargo quality control \\
& & Customs procedures, etc. \\
\hline
\end{tabular}

To shape a comprehensive service offering set for ILUs at a transshipment terminal, the aforementioned services may be divided into groups, as listed below:

1. Available services that are performed within a terminal at certain analyzed moments (these include decisions regarding services included or removed from the comprehensive service offering);

2. Planned services that are planned to be included in the service offering in the future and should be analyzed in detail regarding their possible attractiveness and profitability;

3. New services that are included in the evaluation process to be included in a terminal's offering;

4. Obsolete services that are not profitable or cannot be performed anymore due to a particular set of reasons.

The formulation for a set of comprehensive services at a transshipment terminal is presented in Figure 3. Particular services may be regularly assessed according to a certain 
set of evaluation rules in order to make a decision regarding a particular service-whether it should be added, removed, or left in the comprehensive ILU service offering.

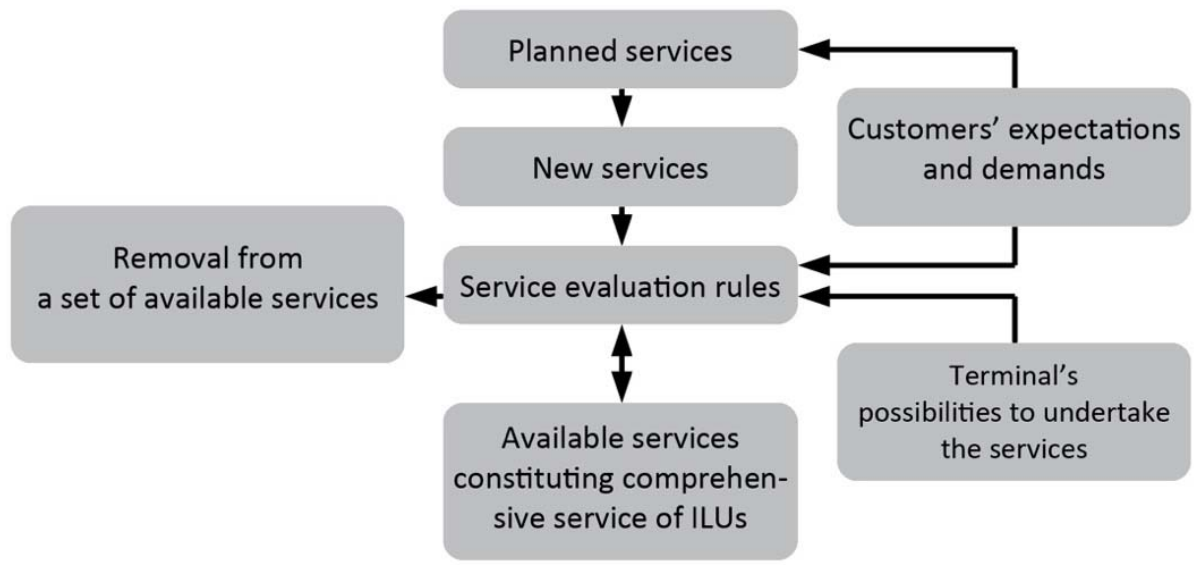

Figure 3. The method of decision making during assessment related to compatibility of available and newly introduced services.

It should be noted that service evaluation rules may differ according to particular transshipment terminals and may include, among others, costs and profits, demands, reliability of services, risk of failure to perform services, operation duration, and other indexes. These terms may form a set of decision-making criteria for the selection of services to formulate a comprehensive service of ILUs at certain transshipment terminalsEquation (1).

$$
C R=\left\{c r_{i}: i=1,2, \ldots, I\right\}, i \in \aleph^{+},
$$

where:

1. $\quad C R$ - a set of decision-making criteria;

2. $\quad c r_{i}$-a sequenced number of a particular criterion, $i=\{1,2, \ldots, I\}$;

3. I-the total number of criteria in a set of decision-making criteria (enumerated criteria).

The criteria may be considered collectively or separately. The descriptions of selected criteria, noted as $\mathrm{cr}_{i}$, and the methods for their assessment are shown in Table 2. The presented criteria mainly cover the profitability of a particular terminal's activity and may be supplemented by other criteria related to, for example, social, economic, and environmental aspects, considering the individual needs of the terminals. The criteria may be calculated independently. One should bear in mind that a company interested in service shaping can choose only selected criteria for evaluation; therefore, a subset of selected criteria must be defined. $C R^{s}$ is the subset of selected criteria, whereas $C R^{s} \subset C R$. In such a case, the evaluation is related to the subset only.

The fulfillment of a criterion or the lack of fulfilment can be examined by means of the assignment of a binary system value to a criterion parameter, as is suggested within Equation (2). $E_{C R}$ is applied when the criteria are considered only for one customer, and $E_{C R J}$ is applied in the case of considering the opinions of more than one customer and the assessment of enlarging the service offerings.

$E_{C R}=\left\{e\left(c r_{i}\right): i=1,2, \ldots, I\right\}, i \in \aleph^{+}, e_{c r i} \in E_{C R} \rightarrow\{0,1\}$,

$E_{C R J}=\left\{e\left(c r_{i} ; j\right): i=1,2, \ldots, I ; j=1,2, \ldots, J\right\}, i \in \aleph^{+}, j \in \aleph^{+}, e\left(c r_{i} ; j\right) \in E_{C R J} \rightarrow\{0,1\}$,

where:

1. $E_{C R}$-a set of binary evaluation of $c r_{i}$ criteria;

2. $E_{C R J}$-a matrix of a binary evaluation of $\mathrm{Cr}_{i}$ criteria, in the case of the opinions of $J$ customers; 
3. j-a consecutive number of a customer who fills out a particular questionnaire (the questionnaire is discussed in further detail in the paper);

4. $e\left(c r_{i}\right)$-a binary evaluation that is equal to one when the $c r_{i}$ criterion is fulfilled; $\left(e\left(c r_{i}\right)=1\right)$ and zero otherwise $\left(e\left(c r_{i}\right)=0\right)$ if the criterion is not a part of a subset $C^{s}$, then its evaluation value is equal to zero by default $-\exists c r_{i} \in C R \backslash C R^{s}: e\left(c r_{i}\right)=0$; similar presumptions occur in the case of $e\left(c r_{i} ; j\right)$.

Table 2. Selected assessment criteria forming the evaluation rules.

\begin{tabular}{|c|c|c|}
\hline Criteria $\left(c r_{i}\right)$ & Method to Assess a Particular Criterion & Comments \\
\hline $\begin{array}{l}\text { A subset of decision-making criteria } \\
\text { related to costs/profits, } c r_{1}, c r_{2}\end{array}$ & $\begin{array}{l}c r_{1}:\left\{\begin{array}{c}\exists K_{s} \leq K_{s a c c} \rightarrow e_{c r 1}=1 \\
\exists K_{s}>K_{s a c c} \rightarrow e_{c r 1}=0\end{array}\right. \\
c r_{2}:\left\{\begin{array}{l}\exists P r_{s} \geq P r_{s a c c} \rightarrow e_{c r 2}=1 \\
\exists P r_{s}<P r_{s a c c} \rightarrow e_{c r 2}=0\end{array}\right.\end{array}$ & $\begin{array}{c}K_{s} \text { - service costs, } K_{s a c c} \text { - service costs } \\
\text { accepted by a decision-maker } \\
P r_{s} \text { - profits from a service performance, } \\
P r_{s a c c} \text { - profits acceptable by a } \\
\text { decision-maker }\end{array}$ \\
\hline $\begin{array}{l}\text { A subset of decision-making criteria } \\
\text { related to demands, } \mathrm{Cr}_{3}\end{array}$ & $c r_{3}:\left\{\begin{array}{l}\exists D_{s} \geq D_{s a c c} \rightarrow e_{c r 3}=1 \\
\exists D_{s}<D_{s a c c} \rightarrow e_{c r 3}=0\end{array}\right.$ & $\begin{array}{c}D_{s} \text { - demand for a service, } \\
D_{\text {sacc }} \text { - demand for a service accepted by } \\
\text { a decision-maker }\end{array}$ \\
\hline $\begin{array}{l}\text { A subset of decision-making criteria } \\
\text { related to reliability of a service/risk of } \\
\text { failure to undertake a service, } c r_{4}, c r_{5}\end{array}$ & $c r_{4}:\left\{\begin{array}{l}\exists N_{s} \geq N_{s a c c} \rightarrow e_{c r 4}=1 \\
\exists N_{s}<N_{s a c c} \rightarrow e_{c r 4}=0\end{array}\right.$ & $\begin{array}{c}N_{s} \text {-reliability of a service, } \\
N_{s a c c} \text {-reliability of a service accepted a } \\
\text { by decision-maker, } R_{s} \text {-risk of failure to } \\
\text { perform a service, } R_{s a c c} \text {-acceptable } \\
\text { value of risk of failure to undertake a } \\
\text { service }\end{array}$ \\
\hline $\begin{array}{l}\text { A subset of decision-making criteria } \\
\text { related to risk of cargo quality decrease, } \\
\qquad r_{6}\end{array}$ & $\begin{array}{l}\exists R_{c s} \leq R_{c s a c c} \rightarrow e_{c r 6}=1 \\
\exists R_{c s}>R_{c s a c c} \rightarrow e_{c r 6}=0\end{array}$ & $\begin{array}{l}R_{c S} \text {-risk of cargo quality decrease when } \\
\text { undertaking a service, } R_{c s a c c}-\text { risk of } \\
\text { cargo quality decrease when undertaking } \\
\text { an accepted service }\end{array}$ \\
\hline $\begin{array}{l}\text { A subset of decision-making criteria } \\
\text { related to duration of a service launch, } \\
\text { provision, } \mathrm{Cr}_{7}, \mathrm{Cr}_{8}\end{array}$ & $\begin{array}{l}c r_{7}:\left\{\begin{array}{l}\exists \tau_{\text {ins }} \leq \tau_{\text {insacc }} \rightarrow e_{c r 7}=1 \\
\exists \tau_{\text {ins }}>\tau_{\text {insacc }} \rightarrow e_{c r 7}=0\end{array}\right. \\
c r_{8}:\left\{\begin{array}{l}\exists \tau_{p s} \geq \tau_{p s a c c} \rightarrow e_{c r 8}=1 \\
\exists \tau_{p s}<\tau_{p s a c c} \rightarrow e_{c r 8}=0\end{array}\right.\end{array}$ & $\begin{array}{c}\tau_{\text {ins }} \text {-duration of service launch, } \\
\tau_{\text {insacc }} \text {-duration of service launch } \\
\text { accepted by a decision-maker, } \\
\tau_{p s} \text {-duration of service provision, } \\
\tau_{p s a c c} \text {-duration of service provision } \\
\text { accepted by a decision-maker }\end{array}$ \\
\hline $\begin{array}{l}\text { A subset of decision-making criteria } \\
\text { related to importance of a service to a } \\
\text { customer, } \mathrm{Cr}_{9}\end{array}$ & $\begin{array}{l}\exists W_{s} \geq W_{s a c c} \rightarrow e_{c r 9}=1 \\
\exists W_{s}<W_{s a c c} \rightarrow e_{c r 9}=0\end{array}$ & $\begin{array}{l}W_{s} \text {-importance of service to a customer, } \\
W_{\text {sacc }} \text { - importance of service to a } \\
\text { customer accepted by a decision-maker }\end{array}$ \\
\hline $\begin{array}{l}\text { A subset of decision-making criteria } \\
\text { related to feasibility of innovative } \\
\text { solutions, } c r_{10}\end{array}$ & $c r_{10}:\left\{\begin{array}{l}\exists F_{s} \geq F_{s a c c} \rightarrow e_{c r 10}=1 \\
\exists F_{S}<F_{s a c c} \rightarrow e_{c r 10}=0\end{array}\right.$ & $\begin{array}{l}F_{S} \text {-feasibility of innovative solutions } \\
\text { within a service, } F_{s a c c}-\text { feasibility of } \\
\text { innovative solutions within a service } \\
\text { accepted by a decision-maker }\end{array}$ \\
\hline $\begin{array}{l}\text { A subset of decision-making criteria } \\
\text { related to compatibility of a service, } c r_{11}\end{array}$ & $\begin{array}{l}\exists C m_{s} \geq C m_{s a c c} \rightarrow e_{c r 11}=1 \\
\exists C m_{s}<C m_{s a c c} \rightarrow e_{c r 11}=0\end{array}$ & $\begin{array}{c}C m_{s} \text {-compatibility of a service, } \\
\mathrm{Cm} \mathrm{m}_{\text {sacc }} \text { - compatibility of a service } \\
\text { accepted by a decision-maker }\end{array}$ \\
\hline $\begin{array}{l}\text { A subset of decision-making criteria } \\
\text { related to flexibility of a service, } c r_{12}\end{array}$ & $\begin{array}{l}\exists F l_{s} \geq F l_{s a c c} \rightarrow e_{c r 12}=1 \\
\exists F l_{s}<F l_{s a c c} \rightarrow e_{c r 12}=0\end{array}$ & $\begin{array}{c}F l_{S} \text {-flexibility of a service, } \\
F l_{s a c c} \text {-flexibility of a service accepted by } \\
\text { a decision-maker }\end{array}$ \\
\hline $\begin{array}{l}\text { A subset of decision-making criteria } \\
\text { related to possibility to undertake a } \\
\text { service by means of outsourcing, } c r_{13}\end{array}$ & $\begin{array}{l}\exists P o_{s} \geq P o_{s a c c} \rightarrow e_{c r 13}=1 \\
\exists P o_{s}<P o_{s a c c} \rightarrow e_{c r 13}=0\end{array}$ & $\begin{array}{l}\mathrm{Po}_{\mathrm{s}} \text {-number of companies that may } \\
\text { undertake a service in outsourcing, } \\
\mathrm{Po}_{\text {sacc }} \text {-number of companies that may } \\
\text { undertake a service in outsourcing } \\
\text { accepted by a decision-maker }\end{array}$ \\
\hline $\begin{array}{l}\text { A subset of energy efficiency and } \\
\text { sustainable energy application, } c r_{14}\end{array}$ & $c r_{14}:\left\{\begin{array}{l}\exists R_{e}=1 \rightarrow e_{c r 14}=1 \\
\exists R_{e}=0 \rightarrow e_{c r 14}=0\end{array}\right.$ & $\begin{array}{c}R_{e} \text {-indicator of energy efficiency and } \\
\text { sustainable energy application (Boolean } \\
\text { assessment) }\end{array}$ \\
\hline
\end{tabular}


The criteria may be evaluated according to the binary rules mentioned in Table 2; nevertheless, if it is not possible to obtain quantitative data (evaluation data) directly from a customer's company (for example, because of trade secrets or inadequate knowledge management), it can be analyzed based on the evaluation questionnaire by omitting Table 2 and using Equation (4) instead. Further in the paper, the authors do not differentiate between equations for a set and a matrix - a matrix is treated as a set when $j$ is assigned to only one customer.

It is worth mentioning that if a new $c r_{i}$ is needed $(i>14)$, Table 2 should be enriched by a new definition of this decision-making criterion and the additional consecutive note $c r_{i}$. In the current version of this model, a binary rating is proposed-either the inclusion of a service in a particular offer is related to the use of sustainable (for example, renewable, electrical) energy in its scope or it is not (it is included as one of the criteria in Table 2). It is a more complex challenge, as it is worth analyzing how energy is exploited in terminals in general and its sources [107]. It is worth mentioning here that in the context of Sustainable Development Goal 7 [108], transshipment terminals as well as other logistics facilities are obliged to increase their energy efficiency. A reduction in the environmental impact and the application of electric and autonomous vehicles in intermodal transport chains is expected [109]. Therefore, clean energy technologies (including sustainable energy and energy-efficient technologies) should also be delivered by a method for new service assessment (in Figure 4).

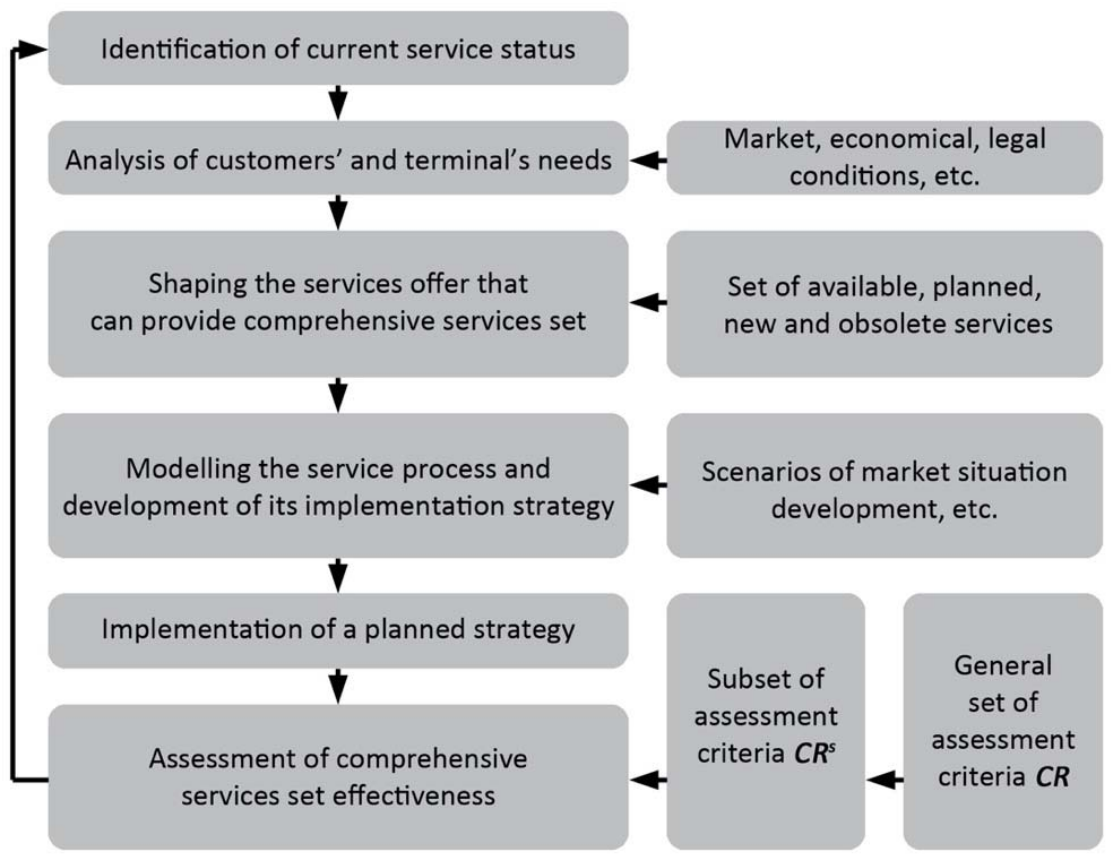

Figure 4. Procedure for formulation of a set of comprehensive services at transshipment terminal.

When individual criteria have been subjected to estimation, it is possible to assess them (as a group). This assessment may help in a making a decision on whether a given service should be included in the set of comprehensive services. It is suggested to also use a ratio of criteria fulfillment for such an evaluation $e_{C R}$, which is calculated as the quotient of the sum of $e_{C R}(i)$ parameters and the criteria population. The value $e_{C R}$ should be compared with the limit, keeping in mind that the limit is set by default ( 0.80 here), and a different value may be adopted depending on the experts' opinion. When $e_{C R} \geq 0.80$, then a particular service can be included in the offering for customers (which means that it can be added to a set of available services carried out as part of a transshipment terminal that is, $S_{a v}$, which is discussed in Section 5 in detail.

Equation (3) is applied when evaluation data are obtained. Otherwise, Equation (4) should be used. The use of Equation (4) is connected to the application of an evaluation 
questionnaire (a sample questionnaire is given further in the paper) filled out by a particular number of customers. The customers assess certain criteria for including particular services in their portfolio. The assessments are given on a Likert scale [110] from 1 to 6 , where 1 is understood as the least important criterion, and 6 is the most important one. According to Equation $(4), q\left(c r_{i} ;\right)=0$ when the opinion of a customer divided by a higher number of points in the applied Likert scale is less than 0.5 , and $q\left(c r_{i j} j\right)=1$ when the opinion of a customer divided by a higher number of points in the Likert scale is equal to or greater than 0.5. If evaluation data are obtained, Equation (4) can be omitted, and the $q\left(c r_{i} ; j\right)$ values correspond to the binary values attributed to $e\left(c r_{i} ; j\right)$, as indicated in Equation (5).

$$
\begin{aligned}
Q_{C R J}=\left\{q\left(c r_{i j} j\right):\right. & i=1,2, \ldots, I ; j=1,2, \ldots, J\}, i \in \aleph^{+}, j \in \aleph^{+}, \\
& q\left(c r_{i ;} ;\right) \in Q_{C R J} \rightarrow\{0,1\},
\end{aligned}
$$

where:

1. $Q_{C R J^{-}}$a set (or a matrix) of binary evaluations of $c r_{i}$ criterion (criteria) in the case of a questionnaire of $J$ customers;

2. $q\left(c r_{i} ; j\right)$-an element of the $Q_{C R J}$ set of binary evaluations of $c r_{i}$ criterion (criteria) in the case of questionnaire of $j$ th customer.

$$
Q_{C R J}=\left\{\begin{array}{c}
\exists\left(\frac{o\left(c r_{i} ; j\right)}{L}\right)<0.5: q\left(c r_{i} ; j\right)=0 ; \\
\exists\left(\frac{o\left(c r_{i} ; j\right)}{L}\right) \geq 0.5: q\left(c r_{i} ; j\right)=1 \\
: i=1,2, \ldots, I ; j=1,2, \ldots, J \\
\quad q\left(c r_{i j} ;\right) \in Q_{C R J} \rightarrow\{0,1\},
\end{array}\right.
$$

where:

3. $o\left(c r_{i} ; j\right)$ - a customer's opinion indicated in the Likert scale (its value is equal to a number of points indicated in the criterion $c r_{i}$ by a $j$ th customer);

4. L-a number of Likert scale points.

After the obtainment of the questionnaire, it can be proclaimed that two sets $E_{C R J}$ and $Q_{C R J}$ correspond with each other, as it is given in Equation (5).

$$
E_{C R J} \equiv Q_{C R J} \equiv\left\{\begin{array}{c}
q\left(c r_{i} ; j\right) \equiv e\left(c r_{i} ; j\right): \\
i=1,2, \ldots, I ; j=1,2, \ldots, J
\end{array}\right\}, i \in \aleph^{+}, j \in \aleph^{+},
$$

In the case of each criterion, a ratio of criterion $e_{C R}(i)$ fulfillment should be estimated based on Equation (6). Such an estimation consists of calculating the average value of the binary evaluation indicator $e\left(c r_{i} ; j\right)$ for all the customer opinions meeting the criterion of the $i$ th number. When all the ratio of criterion $e_{C R}(i)$ values are calculated, that is, the values composed of the set $\boldsymbol{e}_{C R I}$ are known (Equation (7)), it is possible to compute the ratio of criteria fulfillment $e_{C R}$ based on Equation (8).

$$
\begin{gathered}
\forall i \in \aleph^{+}: e_{C R}(i)=\sum_{j \in \aleph^{+}} e\left(c r_{i} ; j\right) / J, e\left(c r_{i} ; j\right) \in\langle 0 ; 1\rangle \wedge J \neq 0, \\
e_{C R I}=\left\{e_{C R}(i): i=1,2, \ldots, I\right\}, i \in \aleph^{+}, \\
e_{C R}=\sum_{i \in \aleph^{+} e_{C R}(i) / I, e\left(c r_{i} ; j\right) \in\langle 0 ; 1\rangle \wedge J \neq 0,}
\end{gathered}
$$

The procedure for the formulation of a set of comprehensive services at a transshipment terminal, given in Figure 4, can be used.

Once the potential new service is assessed with the evaluation criteria, the service complexity at a transshipment terminal should be analyzed (including a new service added to a service offer). The proposed theory related to the service complexity is given in Section 4.2, whereas the application of the obtained research results is discussed in Section 4.3 as verification of the proposed approach. 


\subsection{Approach for the Assessment of the Service Complexity at a Transshipment Terminal}

While considering the possibility of a transshipment terminal handling ILUs, it is important to assess whether a respective terminal meets the requirements in the scope of a comprehensive implementation of individual services for a certain loading unit. When it comes to the actual assessment, it is suggested to use a procedure (Figure 5), where four stages are distinguished as follows.

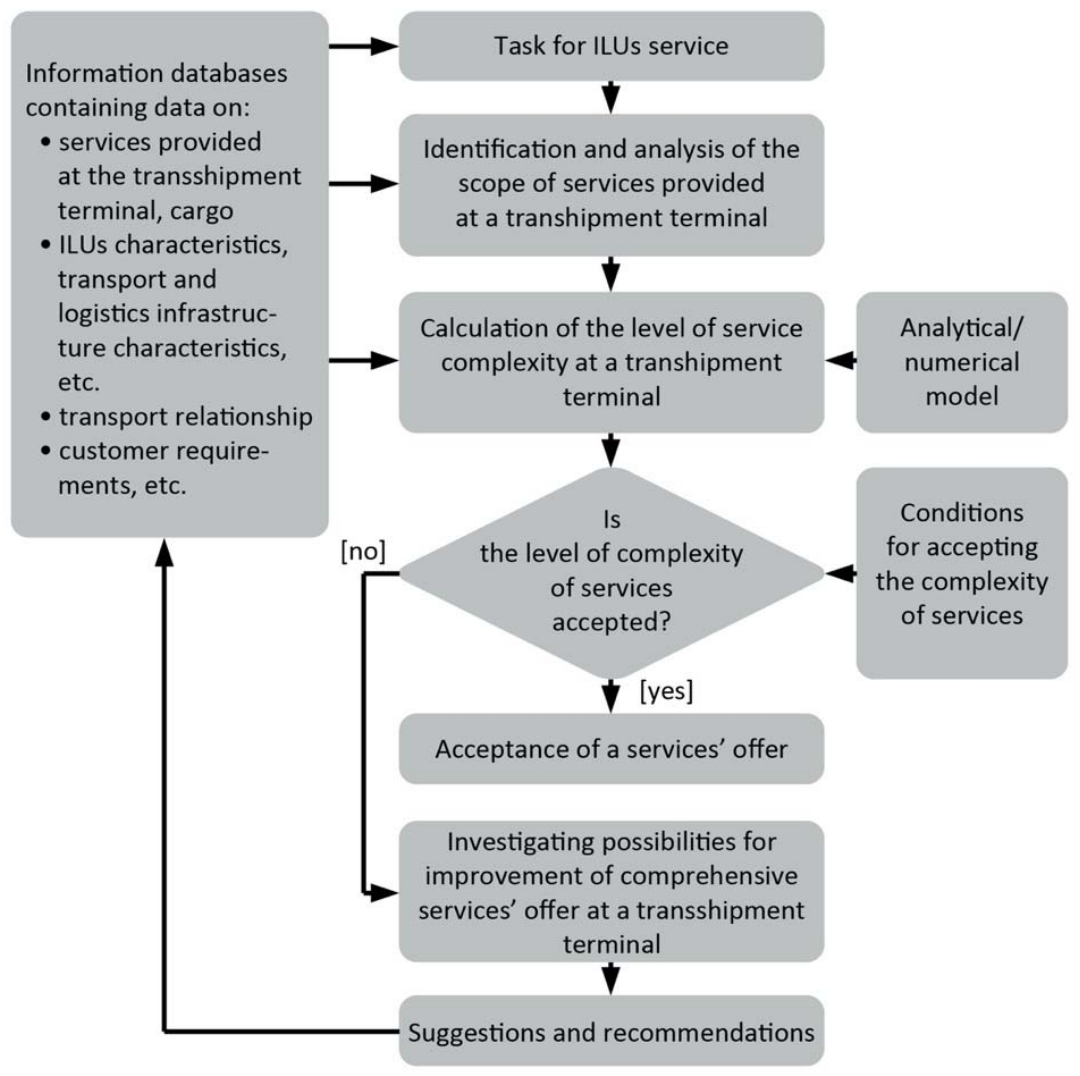

Figure 5. The procedure of assessing the complexity of ILU services at a transshipment terminal.

\subsubsection{Identification and Analysis of Conditions for the Provision of Services}

During this stage, the necessary information and data on the type and conditions of the providing services at a transshipment terminal are gathered to form information databases. These databases should contain information about the available services and customer expectations, ILUs and cargo characteristics, infrastructure and the equipment required to perform the service at the terminal premises, the type of energy used and energy consumption, the possibility of using sustainable energy solutions, and so on. Moreover, the economic, market, legal, and environmental conditions must be examined. These pieces of information can be obtained from market analyses or collected from potential suppliers of services, and so forth.

\subsubsection{Identification and Analysis of Services That Will Be Required}

During this stage, customer requirements specified in the cargo service order are analyzed, and the ability to provide these services by the transshipment terminal is identified and investigated. In order to provide these services, the range of available services at the transshipment terminal is examined.

\subsubsection{Calculation of the Level of Comprehensiveness of Service}

The comprehensiveness level of services $C_{S}$ at the transshipment terminal is assessed by comparing a cardinality of a set of services ordered by a customer (Equation (9)) with a 
cardinality of a set of services available at a certain terminal (Equation (10)) - -this comparison is given here as Equation (11).

$$
S_{a v}=\left\{s_{a v k}: k=1,2, \ldots, K\right\}, k \in \aleph^{+},
$$

where:

1. $S_{a v}$-a set of available services carried out as part of a transshipment terminal;

2. $s_{a v k}$-an available service numbered as $k$.

$$
S_{\text {or }}=\left\{s_{\text {orl }}: l=1,2, \ldots, L\right\}, l \in \aleph^{+},
$$

where:

3. $S_{\text {or }}$-a set of services ordered by a customer;

4. $s_{\text {orl }}$-an ordered service numbered as $l$.

$$
C_{s}=\left|S_{a v}\right| /\left|S_{o r}\right|,\left|S_{a v}\right| \neq 0,\left|S_{o r}\right| \neq 0,
$$

where:

1. $C_{s}$ - comprehensiveness level of services at a transshipment terminal;

2. $\left|S_{a v}\right|-$ a cardinality of a set of available services carried out as part of a transshipment terminal;

3. $\left|S_{o r}\right|$ - a cardinality of a set of services ordered by a customer.

Individual services should be subjected to detailed analysis and the comparison should strive to achieve a situation where $S_{o r} \subset S_{a v}$.

It is worth mentioning that the inversion of the comprehensiveness level of services might be treated as the index of the ordered service efficiency in a terminal. It may be determined by the use of Equation (12).

$$
e_{S}=1 / C_{s}
$$

\subsubsection{Decision Making}

The results of the calculations are compared with the level of service complexity accepted by the decision makers $\left(C_{\text {sacc }}\right.$, Equations (13) and (14)), based on a predefined set of possible decisions (Table 3).

Based on the previous calculation, a decision is made regarding the implementation or introduction of possible changes in the service offering at a selected transshipment terminal. A decision is made according to the conditions given here as Equations (13) and (14).

$$
\begin{aligned}
& C_{s} \rightarrow \text { max }, \\
& C_{s} \geq C_{\text {sacc }},
\end{aligned}
$$

It should be noted that the complexity of services largely depends on the requirements of transshipment terminal customers. Investigating the possibilities of improving the service offering at this point can take place in the following fields:

1. Investments in the development of a comprehensive service offering may require a high level of financial expenses for the operator;

2. Improving the cooperation between stakeholders of ILU services in a terminal that undertakes the introduction of new or modified solutions within the existing structure of the organization;

3. Searching and establishing cooperation with new subcontractors that may need to identify and agree to the terms of cooperation, and so forth, for individual services to be included in a set of comprehensive services. 
Table 3. Examples of acceptance ranges for the level of ILU service complexity at transshipment terminal.

\begin{tabular}{|c|c|c|c|c|}
\hline $\begin{array}{l}\text { Examples of Service } \\
\text { Complexity Levels }\end{array}$ & $\begin{array}{l}\text { Level of Service } \\
\text { Complexity }\end{array}$ & $\begin{array}{l}\text { Acceptance Level of } \\
\text { Service Complexity }\end{array}$ & $\begin{array}{l}\text { Description of the Scope } \\
\text { of ILU Services Rendered }\end{array}$ & $\begin{array}{l}\text { Decision and Further } \\
\text { Steps }\end{array}$ \\
\hline$C_{s} \geq 1.1$ & High & Highly acceptable & $\begin{array}{l}\text { Particular transshipment } \\
\text { terminal provides a wide } \\
\text { range of services }\end{array}$ & $\begin{array}{l}\text { It is recommended to } \\
\text { implement the } \\
\text { comprehensive service } \\
\text { set at a transshipment } \\
\text { terminal }\end{array}$ \\
\hline $1.0 \leq C_{s}<1.1$ & Average & Acceptable & $\begin{array}{l}\text { All required services are } \\
\text { provided at the } \\
\text { transshipment terminal }\end{array}$ & $\begin{array}{c}\text { It is possible to } \\
\text { implement the } \\
\text { comprehensive service } \\
\text { set at a transshipment } \\
\text { terminal }\end{array}$ \\
\hline $0.9 \leq C_{s}<1.0$ & Low & $\begin{array}{l}\text { Conditionally } \\
\text { acceptable }\end{array}$ & $\begin{array}{l}\text { Not all the required } \\
\text { services are provided at a } \\
\text { transshipment terminal; } \\
\text { the arrangement of some of } \\
\text { them requires the } \\
\text { involvement of additional } \\
\text { resources, including } \\
\text { financial ones, or can be } \\
\text { problematic }\end{array}$ & $\begin{array}{l}\text { Modification of service } \\
\text { delivery methods is } \\
\text { required to ensure } \\
\text { delivery of ordered } \\
\text { services }\end{array}$ \\
\hline$C_{S}<0.9$ & Low & Unacceptable & $\begin{array}{l}\text { Not all the ordered services } \\
\text { that are significant for a } \\
\text { customer are available at } \\
\text { certain transshipment } \\
\text { terminals }\end{array}$ & $\begin{array}{l}\text { Service should not be } \\
\text { executed at this point } \\
\text { in time }\end{array}$ \\
\hline
\end{tabular}

\subsection{Verification of the Proposed Approach}

In order to verify the proposed approach, a case study on transshipment terminals located in Poland was considered. Representatives of the transshipment terminals were asked to rank the proposed criteria in the context of the importance of each criterion in their companies. They assessed the criteria taking into consideration the evaluation rules proposed by the authors in Section 4.1 of this paper for including the services in their portfolios. The assessments were given on a Likert scale [110] from 1 to 6, where 1 was understood as the least important criterion, and 6 was the most important one. The mean value of each criterion assessment indicated by the terminal representatives was calculated based on the obtained feedback. As a result, the ranking of the importance of the selected criteria was achieved (Figure 6).

The results of the feedback from the survey respondent analysis indicated that the demand for service and the compatibility of said service with other services are two the most important criteria among the set of decision-making criteria. The duration of the service launch and the possibility of undertaking the service by means of outsourcing were indicated as the least important criteria.

In order to verify the proposed approach, the obtained data (i.e., the insights of the transshipment terminal representatives) were analyzed, using the procedures presented in Sections 4.1 and 4.2. At first, Sections 4.2.1 and 4.2.2 (given in Section 4.2) were considered. Responses from 10 terminals $\left(o\left(c r_{i} ; j\right)\right.$, namely the insights of the transshipment terminal representatives indicated on a Likert scale, were analyzed in detail (Table 4). The authors decided that this data may be used for the analysis of new, hypothetical services to be included in the service offering by treating the obtained data as the insights of ten independent customers who assisted in the assessment of this new service. By applying Equations (2)-(4), at first, the values of $o\left(c r_{i} ; j\right) / L$ were obtained; these were grouped into Table 5. Secondly, a matrix $Q_{C R J}$ of the binary evaluation of the $c r_{i}$ criteria in the case of the questionnaires filled out by $J$ customers is given in Table 6 (excluding the last row of this table). Finally, the set $e_{C R I}$ was generated based on Equations (6) and (7). The results of this set are given in the last row of Table 6. The parameter $e_{C R}$ was calculated according to 
Equation (8) and is equal to $e_{C R} \geq 0.83$. As was mentioned above, when $e_{C R} \geq 0.80$, then a particular service can be included in the offering for customers (which means that it can be added to a set of available services carried out as part of a transshipment terminal i.e., $\boldsymbol{S}_{a v}$ ).

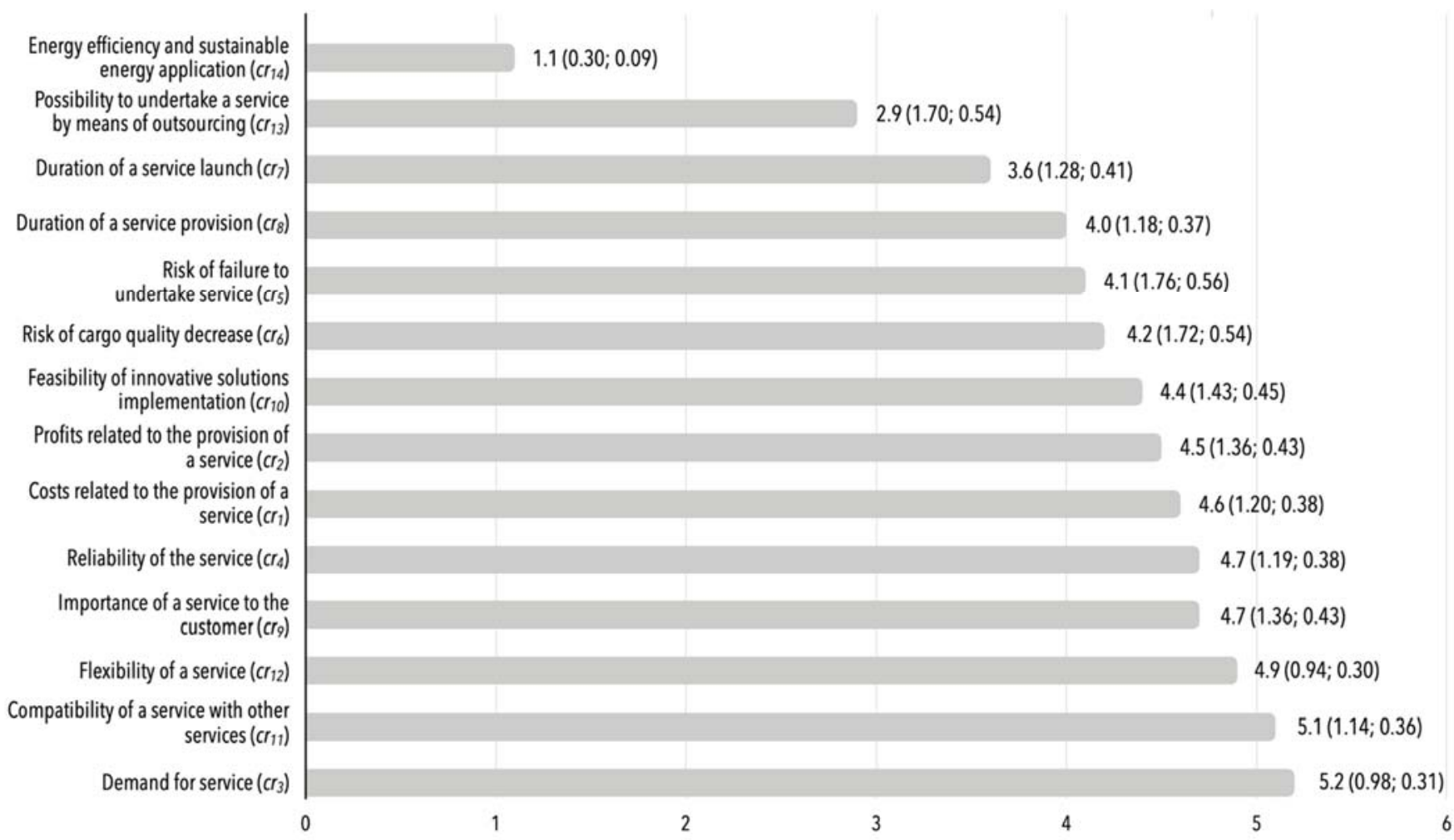

Figure 6. The ranking of importance of the criteria shaping the evaluation rules for including services in a transshipment terminal offering (the mean value for all the answers related to certain assessment criteria is given each time before parenthesis, the standard deviation and the mean squared error of the mean value are given each time in the parentheses, separated by a semicolon).

Table 4. The customer assessment of criteria shaping given in detail.

\begin{tabular}{ccccccccccccccc}
\hline$j$ & $c r_{1}$ & $c r_{2}$ & $c r_{3}$ & $c r_{4}$ & $c r_{5}$ & $c r_{6}$ & $c r_{7}$ & $c r_{8}$ & $c r_{9}$ & $c r_{10}$ & $c r_{11}$ & $c r_{12}$ & $c r_{13}$ & $c r_{14}$ \\
\hline 1 & 5 & 6 & 6 & 5 & 5 & 6 & 3 & 3 & 4 & 4 & 5 & 5 & 4 & 1 \\
2 & 3 & 5 & 4 & 5 & 2 & 2 & 4 & 5 & 5 & 4 & 6 & 5 & 5 & 1 \\
3 & 6 & 6 & 6 & 6 & 6 & 6 & 4 & 4 & 6 & 4 & 6 & 6 & 1 \\
4 & 5 & 3 & 5 & 5 & 5 & 5 & 5 & 5 & 5 & 4 & 5 & 4 & 2 & 1 \\
5 & 5 & 5 & 6 & 3 & 2 & 4 & 2 & 4 & 6 & 6 & 6 & 4 & 3 & 1 \\
6 & 4 & 4 & 3 & 5 & 5 & 3 & 4 & 5 & 5 & 5 & 3 & 5 & 4 \\
7 & 2 & 2 & 5 & 5 & 2 & 2 & 2 & 2 & 5 & 6 & 6 & 6 & 2 \\
8 & 6 & 3 & 6 & 2 & 2 & 2 & 4 & 2 & 1 & 1 & 3 & 3 & 1 \\
9 & 5 & 5 & 5 & 5 & 6 & 6 & 2 & 5 & 5 & 4 & 5 & 5 & 1 \\
10 & 5 & 6 & 6 & 6 & 6 & 6 & 6 & 5 & 5 & 6 & 6 & 6 & 6 \\
\hline
\end{tabular}


Table 5. Recalculation of the customer assessment values into $o\left(c r_{i} ; j\right) / L$ values.

\begin{tabular}{ccccccccccccccc}
\hline$j$ & $c r_{1}$ & $c r_{2}$ & $c r_{3}$ & $c r_{4}$ & $c r_{5}$ & $c r_{6}$ & $c r_{7}$ & $c r_{8}$ & $c r_{9}$ & $c r_{10}$ & $c r_{11}$ & $c r_{12}$ & $c r_{13}$ & $c r_{14}$ \\
\hline 1 & 0.83 & 1.00 & 1.00 & 0.83 & 0.83 & 1.00 & 0.50 & 0.50 & 0.67 & 0.67 & 0.83 & 0.83 & 0.67 & 0.17 \\
2 & 0.50 & 0.83 & 0.67 & 0.83 & 0.33 & 0.33 & 0.67 & 0.83 & 0.83 & 0.67 & 1.00 & 0.83 & 0.83 & 0.17 \\
3 & 1 & 1 & 1 & 1 & 1 & 1 & 0.67 & 0.67 & 1 & 0.67 & 1 & 1 & 0.17 & 0.17 \\
4 & 0.83 & 0.50 & 0.83 & 0.83 & 0.83 & 0.83 & 0.83 & 0.83 & 0.83 & 0.67 & 0.83 & 0.67 & 0.33 & 0.17 \\
5 & 0.83 & 0.83 & 1 & 0.50 & 0.33 & 0.67 & 0.33 & 0.67 & 1 & 1 & 1 & 0.67 & 0.50 & 0.17 \\
6 & 0.67 & 0.67 & 0.50 & 0.83 & 0.83 & 0.50 & 0.67 & 0.83 & 0.83 & 0.83 & 0.50 & 0.83 & 0.67 & 0.17 \\
7 & 0.33 & 0.33 & 0.83 & 0.83 & 0.33 & 0.33 & 0.33 & 0.33 & 0.83 & 1 & 1 & 1 & 0.33 & 0.17 \\
8 & 1 & 0.50 & 1 & 0.33 & 0.33 & 0.33 & 0.67 & 0.33 & 0.17 & 0.17 & 0.5 & 0.50 & 0.17 & 0.17 \\
9 & 0.83 & 0.83 & 0.83 & 0.83 & 1 & 1 & 0.33 & 0.83 & 0.83 & 0.67 & 0.83 & 0.83 & 0.17 & 0.33 \\
10 & 0.83 & 1 & 1 & 1 & 1 & 1 & 1 & 0.83 & 0.83 & 1 & 1 & 1 & 1 & 0.17 \\
\hline
\end{tabular}

Table 6. A matrix of binary evaluation of $c r_{i}$ criteria, in the case of questionnaires filled out by $J$ customers.

\begin{tabular}{ccccccccccccccc}
\hline$j$ & $c r_{1}$ & $c r_{2}$ & $c r_{3}$ & $c r_{4}$ & $c r_{5}$ & $c r_{6}$ & $c r_{7}$ & $c r_{8}$ & $c r_{9}$ & $c r_{10}$ & $c r_{11}$ & $c r_{12}$ & $c r_{13}$ & $c r_{14}$ \\
\hline 1 & 1 & 1 & 1 & 1 & 1 & 1 & 1 & 1 & 1 & 1 & 1 & 1 & 1 \\
2 & 1 & 1 & 1 & 1 & 0 & 0 & 1 & 1 & 1 & 1 & 1 & 1 & 1 & 0 \\
3 & 1 & 1 & 1 & 1 & 1 & 1 & 1 & 1 & 1 & 1 & 1 & 1 & 0 & 0 \\
4 & 1 & 1 & 1 & 1 & 1 & 1 & 1 & 1 & 1 & 1 & 1 & 1 & 0 & 0 \\
5 & 1 & 1 & 1 & 1 & 0 & 1 & 0 & 1 & 1 & 1 & 1 & 1 & 1 \\
6 & 1 & 1 & 1 & 1 & 1 & 1 & 1 & 1 & 1 & 1 & 1 & 1 & 1 \\
7 & 0 & 0 & 1 & 1 & 0 & 0 & 0 & 0 & 1 & 1 & 1 & 1 & 0 \\
8 & 1 & 1 & 1 & 0 & 0 & 0 & 1 & 0 & 0 & 0 & 1 & 1 & 0 & 0 \\
9 & 1 & 1 & 1 & 1 & 1 & 1 & 0 & 1 & 1 & 1 & 1 & 1 & 0 & 0 \\
10 & 1 & 1 & 1 & 1 & 1 & 1 & 1 & 1 & 1 & 1 & 1 & 1 & 1 & 0 \\
$e_{C R}(i)$ & 0.9 & 0.9 & 1.0 & 0.9 & 0.6 & 0.7 & 0.7 & 0.8 & 0.9 & 0.9 & 1.0 & 1.0 & 0.5 & 0.0 \\
\hline
\end{tabular}

Once Sections 4.2.1 and 4.2.2 are realized, the requirements in terms of the comprehensive implementation of individual services for a certain loading unit should be analyzed (Section 4.2.3). To present the application of Section 4.2.3, it was assumed that before the discussed analyses, the transshipment terminal offered four various services. Currently, a set of available services carried out as part of a transshipment terminal $S_{a v}$ increased by one; therefore, the cardinality of the set is equal to $\left|S_{a v}\right|=5$. It was assumed as well that a set of services ordered by a particular customer consists of three elements; therefore, the cardinality of the set is equal to $\left|S_{o r}\right|=3$. Consequently, a comprehensiveness level of services at the transshipment terminal is equal to 1.67 , and the index of the ordered service efficiency in the terminal is 0.60 . Since $C_{s} \geq 1.1$, then according to Table 3 , the level of service complexity was assessed as high and, accordingly, the acceptance level of the service complexity was assessed as highly acceptable. As a result, it can be stated that this hypothetical transshipment terminal provides a wide range of services, and the recommended decision in the approach, finally, is to implement the set of comprehensive services at the transshipment terminal, unambiguously confirming that a new service can be included in the offering for customers.

It is worth noting an important aspect accompanying the described research. In the case of the survey questionnaire research, testing would require survey score reliability. However, the statistical analysis was not the concept of this research; yet, the authors intended to analyze a local (regional) situation related to the issue of the shaping of complex service offerings. The small sample of collected questionnaires does not allow for the computation of a reliable index of Crombach's Alpha (in the sense that the result would not be reliable). However, as a substitute, the authors decided to provide the standard deviation and, consequently, the mean squared error of the mean value, both concerning the answers obtained as a result of filling in the questionnaire and related to particular assessment criteria. The values of the standard deviation and the mean squared error of the 
mean value are given in Figure 6. At the right side of each column in Figure 6 are the mean values for all the answers related to certain assessment criteria; meanwhile, the standard deviations and the mean squared error of the mean values are given in the parentheses, separated by a semicolon.

\section{Discussion and Conclusions}

The results of the theoretical (the proposed formal model) and empirical (criteria assessment based on data obtained from companies for the verification of the proposed approach) research presented in this paper fill the gap in the field of shaping comprehensive services of ILUs in transshipment terminals. A new approach for the assessment of the complexity of ILU services at certain transshipment terminals has been proposed. The procedure for the formulation of a set of comprehensive services at transshipment terminals and the procedure for assessing the complexity of ILU services at the transshipment terminal was developed. The article presents the instrument proposed by the authors to assess the complexity of ILU services at the transshipment terminals (index of ordered service efficiency evaluation) and acceptance ranges to evaluate their level. The conducted research results allowed us to answer the first research question, namely how can the complexity of services be assessed? The proposed formal model, which enables the calculation of the level of service complexity, constitutes the answer to this question. The coupled theoretical and empirical results show a proposed method of conducting such assessments.

The presented approach was verified based on a case study analysis. The questionnaire survey was carried out among the management representatives of transshipment terminals located in Poland. The received feedback provided the possibility of creating the ranking of the proposed criteria's importance during the process of decision making related to the shaping of a transshipment terminal's portfolio. This allowed us to answer the second research question related to the criteria's importance from the point of view of the terminal representatives. Moreover, it was proved that the developed approach may be implemented in practice.

In analyzing the ranking of the proposed criteria's importance, attention should be paid to the criterion of high rates of demand for service. It is commonly known that customers influence service demand. The research results prove that this issue is also significant in the case of transshipment terminals. Therefore, it may be stated that the volume of services needed by customers is the most significant aspect for terminals, providing them the basis for further decisions. Moreover, it should be mentioned that the criterion of the importance of services to the customers also ranked high, at fourth place, after the compatibility of services with other services and the flexibility of services. This also proves the significance of customer impact on services offerings. The last two mentioned criteria show that transshipment terminals perceive the need for adding services without making changes to the existing systems and using existing equipment. This is related to the volume of investments needed before the incorporation of a new solution. Moreover, they note that the services should be easily adjusted to the fluctuations in demand and market changes. However, the criteria related directly to the costs and profits of service provisions placed in the middle of the ranking.

The developed approach is applicable to various loading units, including different container types, swap-bodies, semitrailers, and different terminals and serviced transport modes. Furthermore, it is possible to implement the method to assess service complexity while shaping the offering of a set of comprehensive services not only for a transshipment terminal but for the entire integrated transport chain or various links in the transport chain (logistics facilities other than transshipment terminals), taking into account that individual services can be implemented in its nodes. The implementation of this approach by terminals can allow for facilitating the decision-making process and improving their pursuit of meeting customer expectations. Moreover, it could increase the terminal's level of competitiveness. The presented approach may also become beneficial to other scholars 
in terms of investigating comprehensive service development. It is suggested that all the approaches developed within this study are referenced as the FiDaKo method.

It should be noted that the research results may be influenced by the relatively small number of terminal representatives who filled out the questionnaires, as well as the market environment relevant to the selected region (Poland, in the case of this research). These two limitations impact the answer to the second research question. Considering the abovementioned influences, in regard to the authors of this paper, it is beneficial for future research development to conduct a survey on a larger scale and in other regions, as well as develop an in-depth comparison of the results achieved in Poland with other countries. Nevertheless, on the basis of the achieved data, it was possible to create a ranking of the proposed criteria's importance and validate the approach using actual data. The presented analytical model, corresponding to the presented method, was validated based on qualitative data obtained by the application of questionnaires conducted in Poland solely. Among the future research arrangements, the authors plan to research transshipment terminals in regions than other central Europe. The construction of the model enables us to develop it not only for transshipment terminals; therefore, the continuation of validation is also planned for companies in other sectors operating in logistics and transportation as well.

Moreover, for future reference, it would be interesting to consider the matters related to energy and its efficiency in transshipment terminals around the globe.

The set of criteria used to evaluate the services launched in a terminal's portfolio is still disputable. It should be highlighted that a particular terminal is characterized by its own preferences and the possibilities to adjust its service portfolio to market needs. Moreover, terminals could be willing to use selected criteria from the developed set for further detailed analysis or consider other aspects, including social, legal, environmental, and so on. Therefore, it is important to create the possibility of adding new criteria to this set of open-ended criteria, as well as selecting specific criteria. This indicates the need to examine a broader number of criteria, taking into consideration the individual preferences of particular terminals.

The direction of the authors' further research will cover the improvement of the decision-making model considering different groups of factors that influence the service offerings. Moreover, the authors plan to implement the model as software based on an analytical, simulation, or numerical model [111,112]. It would also be interesting to investigate the influence of market conditions on the perceptions of terminal representatives on the importance of the selected decision-making criteria, as well as broaden the set of the proposed criteria, considering social and environmental aspects. Furthermore, the insights of the terminal representatives and employees of cooperating institutions may be examined to analyze their viewpoints on the shaping of ILU services.

Author Contributions: Conceptualization, L.F.-D. and M.K.; methodology, L.F.-D. and M.K.; formal analysis, M.K.; investigation, L.F.-D. and M.K.; resources, L.F.-D. and M.K.; data curation, L.F.-D.; writing-original draft preparation, L.F.-D. and M.K.; writing—review and editing, L.F.-D. and M.K.; visualization, M.K.; supervision, L.F.-D. and M.K.; project administration, L.F.-D.; funding acquisition, L.F.-D. and M.K. All authors have read and agreed to the published version of the manuscript.

Funding: This research received no external funding.

Institutional Review Board Statement: Not applicable.

Informed Consent Statement: Not applicable.

Data Availability Statement: Data supporting reported results can be obtained in result of a direct contact with corresponding authors.

Acknowledgments: The authors would like to gratefully acknowledge certain transshipment terminal representatives who agreed to complete the survey questionnaire. Moreover, the authors would like to thank all the reviewers involved for their helpful comments and insightful suggestions on 
the manuscript draft. Moreover, the authors would like to thank Nowak W.J. for the support in the linguistic revision of the paper.

Conflicts of Interest: The authors declare no conflict of interest.

\section{References}

1. Notteboom, T.; Parola, F.; Satta, G.; Vonck, I. Deliverable 1.1 \& 1.2 State of the EU Port System-Market Trends and Structure Update. Data Availability, Comparability and Disaggregation. Beneficiary Partner ITMMA-University of Antwerp (UA), University of Genoa (UNIGE). The PORTOPIA Consortium. 2013. Available online: https://www.espo.be/media/D.1.1\%20State\% 20of $\% 20$ the $\% 20 \mathrm{EU} \% 20$ port $\% 20$ system $\% 20 \%$ E2\%80\%93\%20market $\% 20$ trends $\% 20$ and $\% 20$ structure $\% 20$ update_1.pdf (accessed on 1 February 2022).

2. Zhang, R.; Jian, W.; Tavasszy, L. Estimation of network level benefits of reliability improvements in intermodal freight transport. Res. Transp. Econ. 2018, 70,1-8. [CrossRef]

3. Kreutzberger, E.; Konings, R. The challenge of appropriate hub terminal and hub-and-spoke network development for seaports and intermodal rail transport in Europe. Res. Transp. Bus. Manag. 2016, 19, 83-96. [CrossRef]

4. Saeedi, H.; Wiegmans, B.; Behdani, B.; Zuidwijk, R. European intermodal freight transport network: Market structure analysis. J. Transp. Geogr. 2017, 60, 141-154. [CrossRef]

5. Intermodal Transport: Intermodal Loading Units (ILUs). Available online: https:/ / eur-lex.europa.eu/legal-content/EN/TXT/ HTML/? uri=LEGISSUM:124271 (accessed on 1 February 2022).

6. $\quad$ Filina-Dawidowicz, L. Wspomaganie Podejmowania Decyzji w Zakresie Kompleksowej Obsługi Kontenerów Chłodniczych w Zintegrowanych Łańcuchach Transportowych (Decision Support for End-to-End Handling of Refrigerated Containers in Integrated Transport Chains); Oficyna Wydawnicza Politechniki Warszawskiej: Warszawa, Poland, 2018; 209p. (In Polish)

7. Protic, S.M.; Fikar, C.; Voegl, J.; Gronalt, M. Analysing the impact of value added services at intermodal inland terminals. Int. J. Logist. Res. Appl. 2020, 23, 159-177. [CrossRef]

8. Wilmsmeier, G.; Froese, J.; Zotz, A.K. Energy consumption and efficiency: Emerging challenges from reefer trade in South American container terminals. FAL Bull. 2014, 329, 1-9.

9. Wilmsmeier, G.; Spengler, T. Energy consumption and container terminal efficiency. FAL Bull. 2016, 350, 1-10.

10. Spengler, T. Energy Efficiency in Chilean Container Terminals; Hochschule Bremen: Bremen, Germany, 2015.

11. Ye, Z.; Mo, X.; Zhao, L. MINLP Model for Operational Optimization of LNG Terminals. Processes 2021, 9, 599. [CrossRef]

12. Alzahrani, A.; Petri, I.; Rezgui, Y.; Ghoroghi, A. Decarbonisation of seaports: A review and directions for future research. Energy Strategy Rev. 2021, 38, 100727. [CrossRef]

13. Sándor, Z.P.; Csiszár, C. Development stages of intelligent parking information systems for trucks. Acta Polytech. Hung. 2013, 10, 161-174.

14. Beškovnik, B.; Stojaković, M. Establishing an efficient outbound overseas logistics chain of small consignments: The perspective of eastern Adriatic region. Transp. Probl. 2019, 14, 113-125. [CrossRef]

15. Solak Fişkin, C.; Akgül, E.F.; Deveci, D.A. New service development process in intermodal transport: The case of Turkey. JEMS Marit. Sci. 2016, 4, 191-204. [CrossRef]

16. Fadda, E.; Manerba, D.; Cabodi, G.; Camurati, P.E.; Tadei, R. Comparative analysis of models and performance indicators for optimal service facility location. Transp. Res. Part E Logist. Transp. Rev. 2021, 145, 102174. [CrossRef]

17. Galkin, A. System approach for logistics distribution, network's organization and planning. Int. J. Autom. Control Intell. Syst. 2015, 1, 27-33.

18. Rodrigue, J.-P.; Notteboom, T. Dry ports in European and North American intermodal rail systems: Two of a kind? Res. Transp. Bus. Manag. 2012, 5, 4-15. [CrossRef]

19. Rogerson, S.; Santén, V. Business models for dedicated container freight on Swedish inland waterways. Res. Transp. Bus. Manag. 2020, 35, 100466. [CrossRef]

20. Semenov, I.N.; Filina-Dawidowicz, L. Topology-based Approach to the Modernization of Transport and Logistics Systems with Hybrid Architecture. Part 1. Proof-of-Concept study. Arch. Transp. 2017, 43, 105-124. [CrossRef]

21. Shou, Y.; Zhao, X.; Dai, J.; Xu, D. Matching traceability and supply chain coordination: Achieving operational innovation for superior performance. Transp. Res. Part E Logist. Transp. Rev. 2021, 145, 102181. [CrossRef]

22. Wasiak, M.; Jacyna-Gołda, I.; Markowska, K.; Jachimowski, R.; Kłodawski, M.; Izdebski, M. The use of a supply chain configuration model to assess the reliability of logistics processes. Eksploat. I Niezawodn.-Maint. Reliab. 2019, 21, 367-374. [CrossRef]

23. Zhao, K. Design of supply chain task assignment system for international logistics service in coastal area. J. Coast. Res. 2019, 93, 1093-1098. [CrossRef]

24. Fan, D.; Lo, C.K.Y.; Zhou, Y. Sustainability risk in supply bases: The role of complexity and coupling. Transp. Res. Part E Logist. Transp. Rev. 2021, 145, 102175. [CrossRef]

25. Kubicki, J. Koncepcje kompleksowych usług w transporcie międzynarodowym (One-stop service concepts in international transport). Zeszyty Naukowe. Problemy Transportu i Logistyki/Uniwersytet Szczeciński 2010, 12, 91-104. (In Polish)

26. Filina-Dawidowicz, L. Development stages of comprehensive service for perishable cargo at seaports. Ekon. Probl. Ustug 2016, 124, 87-97. [CrossRef] 
27. Antonowicz, M. Intermodal service-System approach. LogForum 2015, 11, 247-258. [CrossRef]

28. Kostrzewski, M.; Kostrzewski, A. Analysis of operations upon entry into intermodal freight terminals. Appl. Sci. 2019, 9, 2558. [CrossRef]

29. Héctor, J.C.; Vis, I.F.A.; Roodbergen, K.J. Transport operations in container terminals: Literature overview, trends, research directions and classification scheme. Eur. J. Oper. Res. 2014, 236, 1-13. [CrossRef]

30. Héctor, J.C.; Vis, I.F.A.; Roodbergen, K.J. Storage yard operations in container terminals: Literature overview, trends, and research directions. Eur. J. Oper. Res. 2014, 235, 412-430. [CrossRef]

31. Steenken, D.; Voß, S.; Stahlbock, R. Container terminal operation and operations research-A classification and literature review. OR Spectr. 2004, 26, 3-49. [CrossRef]

32. Fedtke, S.; Boysen, N. A comparison of different container sorting systems in modern rail-rail transhipment yards. Transp. Res. Part C Emerg. Technol. 2017, 82, 63-87. [CrossRef]

33. Yan, B.; Zhu, X.; Lee, D.-H.; Jin, J.G.; Wang, L. Transhipment operations optimization of sea-rail intermodal container in seaport rail terminals. Comput. Ind. Eng. 2020, 141, 106296. [CrossRef]

34. Reis, V.; Macedo, P. Mapping and evaluating the complexity of information flows in freight transport chains. Transp. Plan. Technol. 2019, 42, 757-776. [CrossRef]

35. Abu Aisha, T.; Ouhimmou, M.; Paquet, M. Optimization of container terminal layouts in the seaport-Case of port of Montreal Sustainability 2020, 12, 1165. [CrossRef]

36. Kim, N.S.; Van Wee, B. The relative importance of factors that influence the break-even distance of intermodal freight transport systems. J. Transp. Geogr. 2011, 19, 859-875. [CrossRef]

37. Matczak, M. A simplified forecasting model for the estimation of container traffic in seaports at a national level-The case of Poland. TransNav 2020, 14, 153-158. [CrossRef]

38. Legato, P.; Mazza, R.M. Queueing analysis for operations modeling in port logistics. Marit. Bus. Rev. 2019, 5, 67-83. [CrossRef]

39. Saeedi, H.; Wiegmans, B.; Behdani, B.; Zuidwijk, R. Analyzing competition in intermodal freight transport networks: The market implication of business consolidation strategies. Res. Transp. Bus. Manag. 2017, 23, 12-20. [CrossRef]

40. Pujats, K.; Golias, M.; Konur, D. A review of game theory applications for seaport cooperation and competition. J. Mar. Sci. Eng. 2020, 8, 100. [CrossRef]

41. Notteboom, T.; Yap, W.Y. Port Competition and Competitiveness. In The Blackwell Companion to Maritime Economics, 1st ed.; Talley, W.K., Ed.; Blackwell Publishing Ltd.: Hoboken, NJ, USA, 2012.

42. Lee, P.W.; Lam, J. Container port competition and competitiveness analysis: Asian major ports. In Handbook of Ocean Container Transport Logistics; Lee, C.Y., Meng, Q., Eds.; International Series in Operations Research \& Management Science; Springer: Cham, Switzerland, 2015; Volume 220, pp. 97-136. [CrossRef]

43. Filina-Dawidowicz, L.; Gajewska, T. Customer satisfaction in the field of comprehensive service of refrigerated containers in seaports. Period. Polytech. Transp. Eng. 2018, 46, 151-157. [CrossRef]

44. Wiegmans, B.W.; Hekkert, M.; Langstraat, M. Can innovations in rail freight transhipment be successful? Transp. Rev. 2007, 27, 103-122. [CrossRef]

45. Rusek, R.; Marsal-Llacuna, M.-L.; Torrent Fontbona, F.; Colomer Llinas, J. Compatibility of municipal services based on service similarity. Cities 2016, 59, 40-47. [CrossRef]

46. Meidute-Kavaliauskienè, I.; Aranskis, A.; Litvinenko, M. Consumer satisfaction with the quality of logistics services. Procedia-Soc. Behav. Sci. 2014, 110, 330-340. [CrossRef]

47. Iliopoulou, C.; Kepaptsoglou, K. Integrated transit route network design and infrastructure planning for on-line electric vehicles. Transp. Res. Part D Transp. Environ. 2019, 77, 178-197. [CrossRef]

48. Ngadiman, N.I.; Roslan, N.F.; Rahman, F.A.; Ahmad, F.; Daud, M.S.M.; Abdullah, R. Survey on quality of services (QoS) at larkin central terminal (LCT), Johor Bahru. Int. J. Adv. Trends Comput. Sci. Eng. 2020, 9, 229-232. [CrossRef]

49. Sayareh, J.; Iranshahi, S.; Golfakhrabadi, N. Service quality evaluation and ranking of container terminal operators. Asian J. Shipp. Logist. 2016, 32, 203-212. [CrossRef]

50. Jafari, H.; Hunson, A.; Jafari, H. Evaluation of customer satisfaction in Iraqi container ports. Int. J. Open Sci. Res. 2013, 3, 1-9.

51. Gajewska, T.; Grigoroudis, E. Importance of logistics services attributes influencing customer satisfaction. In Proceedings of the 4th IEEE International Conference on Advanced Logistics and Transport (ICALT), Valenciennes, France, 20-22 May 2015; pp. 53-58. [CrossRef]

52. Kilibarda, M.; Andrejić, M.; Popović, V. Research in logistics service quality: A systematic literature review. Transport 2020, 35, 224-235. [CrossRef]

53. Gil Saura, I.; Servera Francés, D.; Berenguer Contrí, G.; Fuentes Blasco, M. Logistics service quality: A new way to loyalty. Ind. Manag. Data Syst. 2008, 108, 650-668. [CrossRef]

54. Feng, Y.-X.; Zheng, B.; Tan, J.-R. Exploratory study of logistics service quality scale based on online shopping malls. J. Zhejiang Univ.-Sci. A 2007, 8, 926-931. [CrossRef]

55. Tian, Y.; Ellinger, A.E.; Chen, H. Third-party logistics provider customer orientation and customer firm logistics improvement in China. Int. J. Phys. Distrib. Logist. Manag. 2010, 40, 356-376. [CrossRef]

56. Millen, R.; Sohal, A.; Moss, S. Quality management in the logistics function: An empirical study. Int. J. Qual. Reliab. Manag. 1999, 16, 166-180. [CrossRef] 
57. Gotzamani, K.; Longinidis, P.; Vouzas, F. The logistics services outsourcing dilemma: Quality management and financial performance perspectives. Supply Chain Manag. 2010, 15, 438-453. [CrossRef]

58. Kilibarda, M.; Nikoličić, S.; Andrejić, M. Measurement of logistics service quality in freight forwarding companies. Int. J. Logist. Manag. 2016, 27, 770-794. [CrossRef]

59. Sohn, J.-I.; Woo, S.-H.; Kim, T.-W. Assessment of logistics service quality using the Kano model in a logistics-triadic relationship. Int. J. Logist. Manag. 2017, 28, 680-698. [CrossRef]

60. Murfield, M.; Boone, C.A.; Rutner, P.; Thomas, R. Investigating logistics service quality in omni-channel retailing. Int. J. Phys. Distrib. Logist. Manag. 2017, 47, 263-296. [CrossRef]

61. Mentzer, J.T.; Gomes, R.; Krapfel, R.E. Physical distribution service: A fundamental marketing concept? J. Acad. Mark. Sci. 1989, 17, 53-62. [CrossRef]

62. Rafele, C. Logistic service measurement: A reference framework. J. Manuf. Technol. Manag. 2004, 15, 280-290. [CrossRef]

63. Kisperska-Moroń, D. Logistics customer service levels in Poland: Changes between 1993 and 2001. Int. J. Prod. Econ. 2005, 93-94, 121-128. [CrossRef]

64. Mentzer, J.T.; Flint, D.J.; Kent, J.L. Developing a logistics service quality scale. J. Bus. Logist. 1999, $20,9-32$.

65. Juga, J.; Juntunen, J.; Grant, D.B. Service quality and its relation to satisfaction and loyalty in logistics outsourcing relationships Manag. Serv. Qual. Int. J. 2010, 20, 496-510. [CrossRef]

66. Rafiq, M.; Jaafar, H.S. Measuring customers' perceptions of logistics service quality of 3PL service providers. J. Bus. Logist. 2007, 28, 159-175. [CrossRef]

67. Sohal, A.S.; Millen, R.; Maggard, M.; Moss, S. Quality in logistics: A comparison of practices between Australian and North American/European firms. Int. J. Phys. Distrib. Logist. Manag. 1999, 29, 267-280. [CrossRef]

68. Bouzaabia, R.; Bouzaabia, O.; Capatina, A. Retail logistics service quality: A cross-cultural survey on customer perceptions. Int. J. Retail. Distrib. Manag. 2013, 41, 627-647. [CrossRef]

69. Fung, P.; Wong, A. Case study: Managing for total quality of logistics services in the supply chain. Logist. Inf. Manag. 1998, 11, 324-329. [CrossRef]

70. Hartmann, E.; De Grahl, A. The flexibility of logistics service providers and its impact on customer loyalty: An empirical study. J. Supply Chain Manag. 2011, 47, 63-85. [CrossRef]

71. Lu, J.; Gong, X.; Wang, L. An empirical study of container terminal's service attributes. J. Serv. Sci. Manag. 2011, 4, 97-109. [CrossRef]

72. Liu, W.H.; Xie, D. Quality decision of the logistics service supply chain with service quality guarantee. Int. J. Prod. Res. 2013, 51, 1618-1634. [CrossRef]

73. Pham, T.Y.; Yeo, G.-T. Evaluation of transhipment container terminals' service quality in Vietnam: From the shipping companies perspective. Sustainability 2019, 11, 1503. [CrossRef]

74. Ma, H.-L.; Wong, C.W.-H.; Leung, L.C.; Chung, S.-H. Facility sharing in business-to-business model: A real case study for container terminal operators in Hong Kong port. Int. J. Prod. Econ. 2020, 221, 107483. [CrossRef]

75. Wei, Q.; Xu, Y.; Li, C.; Zhang, Y. Efficiency evaluation of LCL transhipment at port railway container intermodal terminal. J. Coast. Res. 2018, 83, 456-464. [CrossRef]

76. Zimon, D. Impact of the implementation of quality management system on operating cost for small and medium-sized business organizations affiliated to a purchasing group. Int. J. Qual. Res. 2015, 9, 551-564.

77. Castilla-Rodríguez, I.; Expósito-Izquierdo, C.; Melián-Batista, B.; Aguilar, R.M.; Moreno-Vega, J.M. Simulation-optimization for the management of the transhipment operations at maritime container terminals. Expert Syst. Appl. 2020, 139, 112852. [CrossRef]

78. Pokrovskaya, O.; Fedorenko, R. Methods of rating assessment for terminal and logistics complexes. IOP Conf. Ser. Earth Environ. Sci. 2019, 403, 012199. [CrossRef]

79. Jittrapirom, P.; Caiati, V.; Feneri, A.-M.; Ebrahimigharehbaghi, S.; Alonso-González, M.J.; Narayan, J. Mobility as a service: A critical review of definitions, assessments of schemes, and key challenges. Urban Plan. 2017, 2, 13-25. [CrossRef]

80. Chao, S.-L.; Chen, C.-C. Applying a time-space network to reposition reefer containers among major Asian ports. Res. Transp. Bus. Manag. 2015, 17, 65-72. [CrossRef]

81. Costea, A.; Miscoi, G.; Ticu, I.R.; Pomazan, C. Algorithms of evaluation of the waiting time and the modelling of the terminal activity based on the traffic coefficient of ships in the seaport. Ponte Acad. J. 2016, 72, 237-248. [CrossRef]

82. Jiang, X.; Chew, E.; Lee, L. Innovative container terminals to improve global container transport chains. In Handbook of Ocean Container Transport Logistics; Lee, C.Y., Meng, Q., Eds.; International Series in Operations Research \& Management Science; Springer: Cham, Switzerland, 2015; Volume 220, pp. 3-41. [CrossRef]

83. Alam, I.; Perry, C. A customer-oriented new service development process. J. Serv. Mark. 2002, 16, 515-534. [CrossRef]

84. Shekar, A. An innovative model of service development: A process guide for service managers. Innov. J. Public Sect. Innov. J. 2007, 12, 1-18.

85. Marczewska, M. Knowledge as a key resource contributing to the development of eco-innovations by companies-suppliers of environmentally sound technologies. In Proceedings of the CBU International Conference on Innovations in Science and Education, Prague, Czech Republic, 23-25 March 2016; pp. 240-247.

86. Blatnický, M.; Dižo, J.; Blatnická, M. Structural design of soldering station chain conveyor working positions. MATEC Web Conf. 2018, 157, 01002. [CrossRef] 
87. Calderón, F.; Miller, E.J. A literature review of mobility services: Definitions, modelling state-of-the-art, and key considerations for a conceptual modelling framework. Transp. Rev. 2020, 40, 312-332. [CrossRef]

88. Kamargianni, M.; Li, W.; Matyas, M.; Schäfer, A. A critical review of new mobility services for urban transport. Transp. Res. Procedia 2016, 14, 3294-3303. [CrossRef]

89. Macharis, C.; Vanhaverbeke, L.; van Lier, T.; Pekin, E.; Meers, D. Bringing intermodal transport to the potential customers: An interactive modal shift website tool. Res. Transp. Bus. Manag. 2012, 5, 67-77. [CrossRef]

90. Tong, Z.-P.; Xu, Q.-G. Research on transhipment distribution decision under multi-distribution center mode. In Proceedings of the 8th International Conference on Logistics and Systems Engineering 2018, Changsha, China, 6-9 December 2018; pp. 474-482.

91. Ližbetin, J. Methodology for determining the location of intermodal transport terminals for the development of sustainable transport systems: A case study from Slovakia. Sustainability 2019, 11, 1230. [CrossRef]

92. Świderski, A. Analysis and evaluation of the transport services outsourcing. In Proceedings of the 23rd International Scientific Conference Transport Means 2019, Palanga, Lithuania, 2-4 October 2019; pp. 494-498.

93. Macharis, C.; De Witte, A.; Turcksin, L. The Multi-Actor Multi-Criteria Analysis (MAMCA) application in the Flemish long-term decision making process on mobility and logistics. Transp. Policy 2010, 17, 303-311. [CrossRef]

94. Huang, H.; De Smet, Y.; Macharis, C.; Doan, N.A.V. Collaborative decision-making in sustainable mobility: Identifying possible consensuses in the multi-actor multi-criteria analysis based on inverse mixed-integer linear optimization. Int. J. Sustain. Dev. World Ecol. 2021, 28, 64-74. [CrossRef]

95. Guidon, S.; Wicki, M.; Bernauer, T.; Axhausen, K. Transportation service bundling-For whose benefit? Consumer valuation of pure bundling in the passenger transportation market. Transp. Res. Part A Policy Pract. 2020, 131, 91-106. [CrossRef]

96. Jason Chang, S.K.; Chen, H.-Y.; Chen, H.-C. Mobility as a service policy planning, deployments and trials in Taiwan. IATSS Res. 2019, 43, 210-218. [CrossRef]

97. Yang, R.; Liu, Y.; Liu, Y.; Liu, H.; Gan, W. Comprehensive public transport service accessibility index-a new approach based on degree centrality and gravity model. Sustainability 2019, 11, 5634. [CrossRef]

98. Moskolai, J.N.; Houe, R.N.; Karray, M.H.; Archimede, B. Ontology based approach for complexity management in the design of a sustainable urban mobility system. In Proceedings of the IEEE International Conference on Systems, Man and Cybernetics, Bari, Italy, 6-9 October 2019; Volume 8914648, pp. 3223-3228. [CrossRef]

99. Zinn, W.; Parasuraman, A. Scope and intensity of logistics-based strategic alliances: A conceptual classification and managerial implications. Ind. Mark. Manag. 1997, 26, 137-147. [CrossRef]

100. Davis, B.R.; Mentzer, J.T. Logistics service driven loyalty: An exploratory study. J. Bus. Logist. 2006, 27, 53-73. [CrossRef]

101. Neo, H.-Y.; Xie, M.; Tsui, K.-L. Service quality analysis: Case study of a 3PL company. Int. J. Logist. Syst. Manag. 2004, 1, 64-80. [CrossRef]

102. Chen, K.-K.; Chang, C.-T.; Lai, C.-S. Service quality gaps of business customers in the shipping industry. Transp. Res. Part E Logist. Transp. Rev. 2009, 45, 222-237. [CrossRef]

103. Cronin, J.J.; Taylor, S.A. SERVPERF versus SERVQUAL: Reconciling performance-based and perceptions-minus-expectations measurement of service quality. J. Mark. 1994, 58, 125-131. [CrossRef]

104. Kannan, V.R.; Tan, K.C. The impact of operational quality: A supply chain view. Supply Chain Manag. 2007, 12, 14-19. [CrossRef]

105. Thai, V.V.; Tay, W.J.; Tan, R.; Lai, A. Defining service quality in tramp shipping: Conceptual model and empirical evidence. Asian J. Shipp. Logist. 2014, 30, 1-29. [CrossRef]

106. Baki, B.; Basfirinci, C.S.; Murat, I.; Cilingir, Z. An application of integrating SERVQUAL and Kano's model into QFD for logistics services. Asia Pac. J. Mark. Logist. 2009, 21, 106-126. [CrossRef]

107. Acciaro, M.; Ghiara, H.; Cusano, I. The Role of Ports as Energy Managers. In Proceedings of the Annual Conference of the International Association of Maritime Economics (IAME), Marseille, France, 3-5 July 2013.

108. United Nations. Department of Economic and Social Affairs. Sustainable Development Goal 7. Available online: https: //sdgs.un.org/goals/goal7 (accessed on 24 January 2022).

109. Čižiūnienè, K.; Bureika, G.; Matijošius, J. Challenges for Intermodal Transport in the Twenty-First Century: Reduction of Environmental Impact Due the Integration of Green Transport Modes. In Modern Trends and Research in Intermodal Transportation; Sładkowski, A., Ed.; Studies in Systems, Decision and Control; Springer: Cham, Switzerland, 2022; Volume 400, pp. 307-354. [CrossRef]

110. Joshi, A.; Kale, S.; Chandel, S.K.; Pal, D.K. Likert scale: Explored and explained. Br. J. Appl. Sci. Technol. 2015, 7, 396-403. [CrossRef]

111. Huang, Y.; Zhou, Q.; Xiong, X.; Zhao, J. A Cooperative Intermodal Transportation Network Flow Control Method Based on Model Predictive Control. J. Adv. Transp. 2021, 2021, 6658319. [CrossRef]

112. Lopes, H.S.; Lima, R.S.; Leal, F.; Nelson, A.C. Scenario analysis of Brazilian soybean exports via discrete event simulation applied to soybean transportation: The case of Mato Grosso State. Res. Transp. Bus. Manag. 2017, 25, 66-75. [CrossRef] 